\title{
STUDIES ON THE ARCHAEOLOGY OF THE NETHERLANDS ANTILLES: II
}

\author{
A SURVEY OF THE NON-CERAMIC ARTIFACTS OF \\ ARUBA, CURAÇAO AND BONAIRE
}

The Netherlands Antillean islands Aruba, Curaçao and Bonaire are located near the north coast of western Venezuela. The two latter islands are situated 64 and $87 \mathrm{~km}$ from the mainland, and separated by water about 1500 metres deep. Aruba, on the other hand, is on the coastal shelf, and is only 27 kilometres in a direct line from Cape Román, peninsula of Paraguaná; the sea between is shallow and no more than about roo metres deep. It is excellent water for canoe navigation, and is well known for its good fishing grounds.

In I5I5 the greater part of the population was enslaved and carried off by the Spanish; only a few inhabitants were able to escape. When the Dutch West Indian Company took over the island from the Spaniards in I634, they found it inhabited by 73 people who, "being untrustworthy and suspected of being in league with the Spaniards", were expelled to the mainland of South America. Later, Aruba was subjected to a new flow of intruders, this time Indians. In 1816,584 Indians were once again living on the island, and they were described at a later date by VAN KOOLWIJK as: strongly-built, copper-coloured men and women, with wide shoulders, round faces, and wavy, pitchblack hair, erect posture and gait, and possessing innate pride and dignified manners.

There are no longer any true Indians left on Aruba, Curaçao and Bonaire.

\section{Previous Archaeological Work}

Archaeological research in this area can be considered as dating from the year 1878 , when a Roman Catholic priest, Father A. J. van KoolwiJK, was posted to the island of Curaçao. There he was struck by the sight of numerous traces of concentrations of potsherds and sea shells scattered about the area, 
which were obviously the remains of old Indian settlements. The most important sites were on the plantations Knip, Santa Barbara and St. Jan.

In I880 vaN KoolwiJK was transferred to Aruba and it was on this island in particular, where he stayed till $\mathrm{I} 886$, that he started taking a lively interest in archaeology. His investigations were limited to the collection of surface objects and brief excavations. I do not intend to discuss the great merits and the equally great shortcomings of this enthusiastic field-worker, who had no formal training in archaeology but was a keen observer; it is fair, however, to state that his collections are still the most substantial and most important ones available to us. They were presented to the 'Rijksmuseum van Oudheden' at Leyden in the years $1883-85-86$ and 1887 ; in 1903 they were passed on to the 'Rijksmuseum voor Ethnographie', also at Leyden. On January Ist, I935, the name of this museum was changed to 'Rijksmuseum voor Volkenkunde', and it is there that the collections are still kept.

The archaeological objects were mainly obtained at Santa Cruz (a site which has enriched private collections and museums with thousands of specimens), and at Fontein, Savaneta, Tankie Flip and Arikok. They consist chiefly of finely painted earthenware, crude pottery, stone tools, shell tools, ornaments and various burial urns.

In I904, several papers were prepared on the subject of vaN KooLwIJK's collections, and bound together in one volume. This volume was presented at the XLVth International Congress of Americanists, which was held at Stuttgart in the same year (LeEmans, Schmeltz and Koeze: I904).

Dr. H. TEN Kate (Igr6) published a short account of the material, while in later years Professor J. P. B. DE JosseLIN DE JoNG (I9I8, I9I9) devoted an extensive study to it.

In I890, during Van Koolwijk's stay on the island of Aruba, a Frenchman, A. L. Pinart, paid a visit to the island, and in due course published some notes on his findings.

When archaeological interest in the Antilles had almost died, it was Professor DE Josselin DE Jong (I920) who tried to revive it. This scientist left the Netherlands in 1922, and in that year carried out excavations in the islands of Saba and St. Eustatius and in the Virgin Islands, at first in co-operation with the Danish archaeologist Gudmunt HatT, and later on his own (DE JoSSELIN DE JoNG, I923, I947). 
In I923, after he had brought to a close his excavations in this area, he conducted some brief excavations in Curaçao and Aruba, a short account of which will be given in this paper.

Incidentally, Professor De Josselin de Jong's finds have not been described or published before. He very generously afforded us the privilege of analyzing his discoveries and most unselfishly provided us with his diary and field notebook. We therefore started by studying this material, which is now at the Rijksmuseum voor Volkenkunde at Leiden; and, in order to get a better understanding of the archaeology of Aruba and, as far as possible, of Curaçao and Bonaire, we followed up with a careful examination of Van Koolwijk's collections.

Other investigations of the archaeology of the three islands, taken in chronological order, are as follows:

I942. Richard E. SteARNS (I945) paid a short visit to Aruba and described some stone implements.

I948-1950. In unpublished notes, A. D. Ringma described his activities in Aruba and Curaçao: human skeletal remains of presumed antiquity were found in a rock shelter at Koraal Specht and at Hato in Curaçao, and at Canashito in Aruba (cf. WagenaAr HummeLINCK, I959), rock paintings at several localities (cf. WAGENAAR HuMMELINCK, I953, I957).

I95I. During road construction at Savaneta, Aruba, an almost complete, pear-shaped burial urn was discovered, containing parts of deer antlers and a millstone (Beurs- en Nieuwsberichten, May 9th, I95I).

I95I, I958. Dr. HANS Feriz (I959) visited the three islands. He described various rock paintings at Papillon and Canashito, and discovered a griddle at Hadi-Koenari in Aruba.

I953. When a sand pit was dug at Seroe Noka in Aruba, two burial urns containing human bones were unearthed. It appeared that remains of three or four individuals had been inhumed in one urn, pointing to secondary, multiple urn burial. A large fragment of a griddle was found in the same urn. The urn field, about $300 \mathrm{sq}$. metres in area was later destroyed by bulldozers (FERIZ, I959, p. I03-I04).

I953. Professor J. M. CRUXent of Caracas carried out excavations for seven days at Santa Cruz in Aruba. 
He obtained a very substantial body of data. Thus far, no paper has appeared on his excavations (Aruba Esso Nerws, June I9th, I953).

I956.

By chance, according to a local paper (Beurs, June Ist I956) another burial urn was unearthed at Savaneta in Aruba, by K. J. van GaAlen. The urn contained a human skull, parts of jaws and teeth, and pierced shell beads. It was a clear instance of single secondary urn-burial.

The above summary of archaeological work done is not complete, as, in addition to archaeological objects found on and in the ground, the islands of Aruba, Curaçao and Bonaire have yielded many rock paintings which are difficult to describe. These paintings are characterized by the use of curvilinear patterns and, more rarely, animal and human figures. G. B. Bosch (I836, p. 2I9-220) was the first to report them. Since then, the subject has received much attention; later notes on it have been made by TeEnstra (I837), van KoolwiJk (I882, I885), Martin (I885, I888), Pinart (I890), Mallery (I893), EuWens (I907, I9II), ten Kate (I9I6), AmelunXen (I929), Wollebaek (I934), Realino (I938), Rings (I943), WesterMANN (I947) and Hartog (I95I, I953). The most extensive contribution on the rock paintings has been published by Dr. P. WagenaAR HummelincK (1953, I957) which also deals with the publications of all the above-mentioned authors. The rock paintings were found on the walls of rock shelters and on diorite blocks; they had been executed, as a rule, in a brownish-red paste, more rarely in whitish, yellowish or bluish colours.

\section{De Josselin de Jong's investigations in Curaçao and Aruba}

We shall now briefly review the investigations carried out by Professor DE JosselIN DE JoNG in Curaçao and Aruba, respectively. The data have been extracted from his diary and his field record book.

After bringing to a close his researches in Saba and St. Eustatius (I922), he went to Curaçao where he arrived on June 4th, I923, and examined the following sites.

Asiento: June 6th and I6th. - A visit was paid to an ancient Indian site from which vaN KooLwIJK had amassed a collection of archaeological specimens. The area had suffered heavy erosion. It was littered with potsherds, shells, fragments of stone tools, 
and shell ornaments, and in several places the bare diorite rock was exposed on the surface. Only in a few places were deposits detected, not more than Io- $15 \mathrm{~cm}$ in thickness, which contained artifacts.

St. Jan: June 8th - I6th. - One day was spent in surface exploration of this site, which is prolific of finds. The next day a trial trench four metres long and one metre wide was started, and finished on the same day. A second trench six metres long and one metre wide was then begun, and completed by June I6th. The site appeared to be very shallow; rock was usually reached at a depth of $30 \mathrm{~cm}$ and, less frequently, at a depth of $50 \mathrm{~cm}$. In addition to artifacts, an ill-preserved human skeleton was found near the rock bottom. It was lying on its left side in a horizontal position with slightly bent legs, the head towards the south. It was not possible to remove the skeleton. A small chisel made of green stone was found on the surface.

Knip: June gth. - Shell tools were collected from the surface.

Santa Barbara: June Igth. - Shells were picked up from the surface of the three small peninsulas east of the old country house.

Brievengat: June 6th and 2oth. - Only a few sherds were collected from the surface.

Schottegat: June 2rth. - There is some evidence of the existence of an ancient Indian settlement here. Only a few sherds were found on the surface.

From the foregoing, it would appear that something like six localities could be put on record. It should be emphasized, however, that, on account of the shallowness of the deposits, no stratigraphic division was apparent, and speculation as to such a division seems futile before new approaches have been made. More attention may well be given to this aspect in future when excavations of non-ceramic archaeological sites are carried out. It seems reasonably probable that such sites contain the material culture of the first immigrants, people who lived on a basic cultural plan, used shell gouges, and were wholly ignorant of agriculture.

DE Josselin DE Jong left Curaçao by sail and arrived at Oranjestad, Aruba, on June 27th. On the very next day a reconnaissance trip was made to Santa Cruz, east of the Hooiberg, a site where erosion had laid bare numerous sea shells and artifacts, and which had previously attracted many workers and collectors. It was at this site that VAN KoOLwIJK made his most 
substantial collections, and DE JosSELIN DE JoNG called it Santa Cruz A. Two similar sites were located, respectively further north and northeast near Piedra Plat, and these he named Santa Cruz $B$ and $C$. The three sites were selected for brief excavation, or, to be more precise, for excavation by a system of simple trenching. Their surfaces were eroded, and disturbed by recent tilling, and they were covered with scattered shells and artifacts. The earth was found to be hard and dry, and difficult to dig.

Santa Cruz A: June 28th - July 6th. - The first step taken was to mark out a trench twenty metres long and one metre wide. The area of the trench was then divided into one-metre squares, and the squares excavated one after another in search of archaeological objects. In each square, layers of $25 \mathrm{~cm}$ were taken each time, and as the total thickness of the refuse deposits was usually less than $50 \mathrm{~cm}$ and only occasionally as much as $60 \mathrm{~cm}$, two layers sufficed. It appeared that most finds were concentrated in the upper layer, except in the third square, where potsherds were continually being found down to a depth of $60 \mathrm{~cm}$. The second and third squares provided the bulk of the finds, whereas the fourth, fifth and sixth produced only a few objects. The refuse deposit at this last square was not more than ro $\mathrm{cm}$ thick in places. Sea shells and potsherds formed the bulk of the refuse, but there were also shell gouges, stone celts and a few animal bones. No evidence of house structures or post-holes was found, and it has not yet been possible to determine the boundaries of the settlement. No stratification whatsoever was apparent, and the same is the case with all other sites in Aruba discovered so far.

Santa Cruz B. - When the excavation work at Santa Cruz A had been completed, operations started at Santa Cruz B. After two one-metre squares had been examined, it appeared that this site was too shallow and the finds too scanty to be of interest. Excavations were therefore discontinued.

Santa Cruz C. - A trench ten metres long and one metre wide was excavated. In the fifth square an inverted urn covering the scattered remains of a human embryo was found, together with various potsherds and other artifacts. The operations were finished by July IIth.

Savaneta: July I2th - July I5th. - A trench eight metres long and one metre wide was marked out at Savaneta, north-east of Commandeursbaai. The same system of simple excavation was followed as that employed at Santa Cruz. In the fifth square a 
large urn with cover was brought to light containing the remains of a human skeleton lying at the bottom. The urn was filled with earth, shell fragments, sherds of finely made and of crude earthenware, and some stones, while at the bottom there was a piece of a glass bottle, suggesting that the tradition of urn burial continued into historic times, and confirming the accounts of early European travellers about the practice of urn burial in the beginning of the nineteenth century. The urn was found $36 \mathrm{~cm}$ below the surface, at a place where the bare rock bottom was reached at I.25 metres.

Fontein: July r6th. - A trip was made to the rock paintings. An excavation on a small scale was started under a rock shelter, and reached a depth of r.8o metres. Nothing was found except a millstone, perhaps employed for pulverizing the red and yellow ochre with which the rock paintings were made.

Santa Cruz D: July I8th. - South of the Roman Catholic church, an urn was discovered and unearthed. This urn contained a human skull and two small pots. On the same site a large earthenware pot was found which was placed inverted over an adult human skeleton. Finally, a small burial urn was found which contained some human bones. A separate human skull was discovered between the two urns; it has been suggested by DE JosSELIN DE Jong that the skull had originally been in the small urn.

Such, in brief, is the outline of DE JOSSELIN DE JONG's investigations in Curaçao and Aruba. The finds have been carefully studied by DU RY and the present author. The objects are kept at the 'Rijksmuseum voor Volkenkunde' at Leiden, where they have been numbered and catalogued.

\section{ECONOMIC Life}

In Aruba deposits of refuse from old Indian settlements have been found near the open shore at Savaneta, and also inland at Santa Cruz. These refuse heaps contain not only large amounts of edible shellfish and crab remains, but also fish and turtle bones. It is obvious that the inhabitants obtained a large part of their livelihood from the sea. The men probably went out fishing, and the women collected shellfish and crabs.

The economic life of Aruba was apparently quite intimately related to local ecological conditions. The people did some hunting, although there was little wild life on the island. Very 
few bones of mammals and birds were found in refuse middens; the first have been described by HoorJer (I960).

There were limited possibilities for agriculture in this dry, scrub country, with its deficient rainfall and lack of fresh water, although the vegetation seems to have been much denser in former times than it is at present. There is also evidence of some primitive form of agriculture. Large fragments of clay griddles, ranging from $\mathrm{I} 6 \mathrm{~mm}$ to $2 \mathrm{Im}$ in thickness, were reported by BARTELS (1953) from the Seroe Noka site and were recognized among potsherds in Aruba by DU RY; and a few smaller fragments are known from the islands of Curaçao and Bonaire. The griddles were used for baking bitter cassava (manioc). True metates are absent, but grinders and mortars have been found at several sites, pointing perhaps to seed planting. It is obvious, however, that the population's diet was chiefly marine.

The people probably wore little clothing, and weaving was perhaps unknown, as no true spindle whorls have been discovered. Nor is there any evidence that domestic animals were kept.

It looks as if the island was inhabited at that time by a small community which supported itself by a self-sufficient fishinggathering-gardening economy. Salt and shell beads were probably used for the earliest maritime staple trade between Aruba and the continent of South America.

The shell middens of Aruba, whose soil has been repeatedly disturbed recently by ploughing, are, like those of the Dabajuro sites, no more than $25-50 \mathrm{~cm}$ in thickness. In this shallow layer, no cultural depth was apparent; the finds must therefore be classified as unstratified unit collections, and it has been necessary to concentrate largely on typology and geographical distribution.

No traces of permanent structures have come to light so far, and we have no idea yet of the size of the settlement.

Aspects of life, other than those already mentioned, are revealed by the abundance of archaeological finds in the refuse deposits. The bulk of these finds are potsherds, with which, however, I shall not deal, as they have already been discussed and analyzed in detail by $\mathrm{DU} \mathrm{RY}$ in the preceding paper. For the sake of clarity, the terminology of CRUXENT \& Rouse (I958) has been followed in describing the non-ceramic artifacts. 


\section{Sheli. Artifacts}

Relatively large numbers of sea shells were utilized. Most characteristic among the shell artifacts are the gouges, which fall naturally into three categories:

(a) Shell gouges of simple construction made from the outer whorl of the conch shell (Strombus gigas) (Pl. XXIII, I). (This and the following shells have been identified for me through the courtesy of Dr. C. O. van Regteren Altena, 'Rijksmuseum van Natuurlijke Historie', Leiden).

They are roughly oval or triangular in shape, and have a welldefined cutting edge which is made by grinding one or sometimes both surfaces of the bit. No secondary working is carried out on the remainder of the object, which is left rough and unground. These shell gouges are common in Aruba, Curaçao and Bonaire. Similar shell gouges are well known from pre-ceramic shell middens on the east coast of Venezuela and its adjacent islands. Their first appearance has been recorded by Rouse \& CRUXENT (1958, p. 240) in the Manicuare complex of Period I and the first part of Period II, and they also seem to occur in the non-ceramic shell heaps of Cuba and Haiti, where they were manufactured and used by the Ciboney, simple fisherfolk and collectors who, at the time, were distributed over a wide area (CRUXENT \& Rouse, I958, p. 24I. RouSE, I956, p. I66-I68. OSGOOD, I942).

Thus far, non-ceramic shell middens containing shell and bone tools, have not been discovered on our islands off the Falcón coast. But it can hardly be doubted that they are to be found there.

The shell gouges are perhaps to be considered as marginal survivals or relics which have persisted for long periods. Another possibility is that they originated and were developed at different periods and places.

(b) Modified shell gouges are typologically more advanced, in the sense that their side edges have also been ground, by rubbing the concave side of the shell against a flat stone. As a result of the grinding, long parallel facets can easily be recognized on the side edges (Pl. XXIII, 2). Modified shell gouges are known as surface finds from the Lesser Antilles. On the island of Aruba they are rare, but they are common in Curaçao.

(c) Shell celts are ground on both surfaces as well, the end 
products being completely ground shell tools (Pl. XXIII, 3). Many examples are known from different sites in Curaçao, but only a few have been found in Aruba, all at Santa Cruz.

Shell gouges, modified shell gouges, and shell celts were made from Strombus gigas and were employed, in conjunction with a fire of some kind, in hollowing-out trees to make canoes.

Parts of the conch shell were also fashioned into simple spoons, cups, plates and ornaments (Pl. XXIII, 4, 5). Small, flat, discoidal shell beads (Pl. XXIV, 4, 5) are found in abundance in Aruba and Curaçao. They form parts of necklaces. Holes are pierced in the centre, and the size varies from $9 \mathrm{~mm}$ in diameter by $2 \mathrm{~mm}$ in thickness to $22 \mathrm{~mm}$ in diameter by $5 \mathrm{~mm}$ in thickness. In some cases shell beads of this type have been found in Aruba as funeral gifts. Similar ornaments, but drilled on one side with two holes converging into one hole on the opposite surface, are called "button-like objects" (Pl. XXIV, 2); only a few examples are known from Aruba and Curaçao. They have also been reported from the peninsula of Cabrera (KIDDER, I944, p. 75).

Larger disc-like shell objects are much like the shell beads just described, the only difference being that they are not pierced for suspension (Pl. XXIII, 6, 7); their function is uncertain, but perhaps they serve the same purpose as the mysterious potsherd discs described by du RY on page 93 and 95. Many examples are found in Aruba and Curaçao.

Other shell work includes pendants, amulets and rings; also small whole shells (Amphiperas cyphoma gibbosum L.) from Aruba and Curaçao, pierced with one or, more frequently, four holes (Pl. XXIV, 9, I0). Only a few specimens are known.

Further peculiar items are: part of an Oliva shell with a deep horizontal notch in one edge, from Aruba (Pl. XXIV, I5) - it has its counterpart in the Barcelona area of north-east Venezuela (OsGood \& HowARD, I943, pl. 5g); a pierced Ostrea sp. and a whole Oliva Strephona reticularis Lam. with a round hole pierced in the top, both from Asiento, Curaçao. Beads and pendants are types frequently found, in contrast to rings, of which there are only two examples. One, a fragment of what seems to be a nosering, with two holes, from Aruba (Pl. XXIV, I); the other, a very small ring found at Asiento, Curaçao (Pl. XXIV, 7). Earplugs are rare; one massive example is known from Santa Cruz in Aruba (PI. XXIV, II), another, smaller but beautifully carved and ground from Curaçao (Pl. XXIV, I6). 
Plate I

Bulging collar jar with human features in appliqué. Black painting has been applied directly on the unslipped body and covers the whole shoulder surface. H. $45 \mathrm{~cm}$; diam. $38 \mathrm{~cm}$. - All photographs have been taken by P. ZWANENBURG, Leiden.

$\mathrm{KW}{ }_{1403 / 50}$.

\section{Plate II}

I, 2, 3, 6 and 8, supposed 'Cedros style' sherds. Incised crosshatched pattern. 4, brown-painted white-slipped rimsherd. 5, plain sherd with serpent in appliqué work. 7, red-on-plain adorno with incision and punctuation.

I. JJ 3568/182; 2. JJ 3568/456; 3. JJ 3569/175; 4. JJ 3568/103; 5. JJ 3568/187; 6. JJ 3568/172; 7. Kw $1403 / 228 ; 8$. JJ $3568 / 176$.

Plate III

$1,2,3$, bottle necks of a plain type with an applied ridge. 4 and 6 , specimens showing shell and mica tempering. 7 and 8 , fabric-impressed sherds. 9, corrugated rimsherd showing marks of finger impressions.

1. JJ $3568 / 615$; 2. JJ 3568/123; 3. Kw 1403/55; 4. WH 3636/1; 5. JJ 3568/650; 6 . WH 3636/2; 7 JJ 3568/341; 8. JJ 3568/699; 9. JJ 3568/217.

Plate IV

I, perforated annular base. 2, heavy solid leg. 3, flat base. 4, hollow basal fragment in which superposed coils are visible. 5, open annular base with support.

I. JJ 3568/614; 2. Kw 1403/153; 3. JJ 3568/511; 4. JJ 3568/610; 5. Kw 1403/562.

Plate V

I, leg; black-on-red painted type; only the upper part is hollow. 2, solid plain leg with a notched lug on top. 3 , hollow leg; black-on-red painted type with zoomorphic lug on top. This leg is pierced on two sides. 4, hollow leg; black-on-white painted type. 5, perforated, partly hollow leg; black-on-white painted type. 6, hollow, anthropomorphic leg of a plain type. 7 , solid leg of an indeterminable type, with a chain-like ornament just above the foot. 8 and 9 , solid, notched, feet of a plain type. Io, solid leg with concentric carved rings.

I. JJ 3568/554; 2. Kw 1403/164; 3. Kw 1403/609; 4. Kw 1403/576; 5. JJ 3568/127; 6. Kw 1403/ 249; 7. JJ $3568 / 447$; 8. JJ $3568 / 531$; 9. JJ $3568 / 229$; 10. Kw I403/75I.

\section{Plate VI}

I, 4 and 6, annular base fragments with zoomorphic supports. I, shows a fragment of a vessel fixed to the support. The three specimens belong to the black-on-white painted type. 2, fragment of a leg-and-ring base. 3 , red-on-tan painted fragment of an annular base. 5, double-rodded grip of a plain vessel. 7, 8 and 9, handles of black-on-white painted bowls. 1. Kw $1403 / 600$; 2. JJ 3568/480; 3. Kw $1403 / 172$; 4. JJ 3568/763; 5. JJ 3568/582; 6. JJ 3568/60/ 7. KW $1403 / 574$; 8. JJ 3568/130; 9. JJ 3568/103.

\section{Plate VII}

I, pierced, red-on-red painted handle fragment with human features accentuated by knobs. 2, red and black-on-red painted handle fragment with coffee-bean elements. 3, black-on-red painted handle with a human face on the central support. 4, plain handle fragment with a coffee-bean eye and a cock's-comb rim. 5 and 6, polychrome; black and red on red painted handle fragment. No. 6 has a coffee-bean eye on the reverse side. I. JJ 3568/647; 2. JJ 3568/664; 3. JJ 3568/648; 4. JJ 3568/590; 5. JJ 3568/643; 6. JJ 3568/604. 
Plate VIII

I, lug, placed vertically on a plain vessel wall. 2, ear, with rings at its ends, black-on-white type. 3 , lug on a plain-type vessel wall. 4, plain ear with punctuated ring at one end. 5, bitubular handle ending in human features inside the vessel wall. 6 , ear on a hollow rim of the black-onwhite type. 7 , plain ear with notched ends. 8 and 9, plain ears. ro, zoomorphic lug. I I, black-on-white handle.

r. JJ 3568/589; 2. JJ 3568/914; 3. JJ 3568/r98; 4. Kw 1403/219; 5. JJ 3568/640; 6. Kw 1403/468; 7. Kw 1403/473; 8. JJ 3568/66r; 9. JJ 3568/592; I0. Kw I403/292; II. Kw I403/573.

\section{Plate IX}

I, pierced lug. 2 and 3, plain-type ears. 4, elbow-shaped, punctuated ear. 5, plain-type ear with two notched knobs. 6, zoomorphic lug on a blackon-white painted rimsherd. 7,9 and II, plain-type ears. 8, black-onwhite painted ear. Io, zoomorphic ear.

I. JJ 3568/430; 2. Kw 1403/208; 3. Kw 1403/752; 4. Kw 1403/577; 5. Kw 1403/29I; 6. JJ 3568/ 596 ; 7. Kw 1403/207; 8. Kw 1403/215; 9. JJ 3568/357; 10. JJ 3568/85; 11. Kw 1403/575.

\section{Plate X}

I, frog motif in appliqué on black-on-white type. 2 and 8 , probably bat's heads; plain type. 3, claw of a bird; black-on-white painted type. 4, little frog; plain type. 5, head of a frog (?); black-on-white type. 6 and 7 , frog motifs on black-on-red painted type. 9, punctuated serpent on a plain sherd.

I. Kw $1403 / 297 ; 2$. Kw $1403 / 737 ; 3$. Kw $1403 / 63 \mathrm{r} ; 4$. Kw $1403 / 296 ; 5$. Kw 1403/624; 6. Kw $1403 /$ $8 \mathrm{IA} ; 7 . \mathrm{KW} \mathrm{I}_{4} \mathrm{03} / 295$; 8. JJ 3568/546; 9. Kw I403/472.

\section{Plate XI}

I, plain-type earthenware; human face, with globular eyes and a vertical lump of clay as nose, with an indication of the nostrils. Drill holes are visible on both sides of the eyes. 2, white-slipped, human face with a small bulging nose and carvings indicating eyes and mouth. 3, black-onplain painted type; encircled knobs as human eyes (?). 4, two small ears forming the eyes of a human face on a black-on-white painted bowl. 5, black-on-plain type coffee-bean elements and arching eyebrows applied in lumps of clay. 6, same as 5 , with larger coffee-bean elements. 7 , blackon-white type; human head. 8, plain-type earthenware; human head with coffee-bean eyes and a lump of clay for the nose, with indicated nostrils. Incipient drill holes are visible on the lower left and on the right sides. 9, large coffee-bean eye and button-shaped bosses on a plain rimsherd.

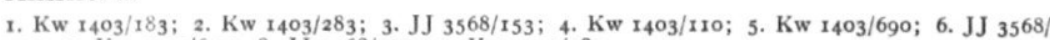
$195 ; 7 . \mathrm{Kw} 1403 / 619 ; 8$. JJ 3568/375; 9 . Kw $1403 / 28 \mathrm{r}$.

\section{Plate Xil}

I, zoomorphic spout of the black-on-white type. 2, zoomorphic spout of the black-on-red type. 3, black-on-white type spout. 4, 6, 7, 8 and 9 , incised sherds covered with a red slip. 5, zoomorphic spout of the blackon-white type.

r. JJ $3568 / 766$; 2. JJ $3568 / 945 ;$ 3. JJ $3568 / 668 ; 4$. JJ $3568 / 455 ;$ 5. JJ 3568/782; 6. JJ 3568/179; 7. JJ 3568/174; 8. JJ 3568/353; 9. JJ 3568/173.

\section{Plate XIII}

I and ro, show the combination of painting and appliqué work. The designs on the other sherds speak for themselves.

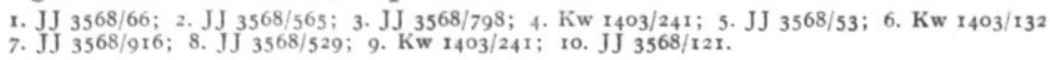


Plate XIV

I, 6, 7 and 9, black painting on a red lustrous slip. 2, polychrome type; black and red on an orange-coloured slip. 3, brown painted design on a tan-coloured slip. 4 and 5, black painting on a chalky red slip. 8 and ro, red painting on a lustrous red slip.

I. Kw I403/233; 2. JJ 3568/670; 3. JJ 3568/32; 4. JJ 3568/672; 5. JJ 3568/671; 6. JJ 3568/875; 7. Kw I403/706; 8. JJ 3568/705; 9. JJ 3568/140; ro. Kw $1403 / 707$,

Plate XV

I, 2 and 3, fragments of incised cylinders. 4, spindle-whorl, stamp or ear-plug? 5, griddle fragment. 6, incised cylinder: when rolled in the soft clay it will give a positive design. 7 , stem of a clay pipe. 8 , incised and punctuated cylindrical object. 9 and ro, topia or cylindrical pottery discs.

r. Kw $1403 / 332$; 2. Kw 1403/484; 3. Kw 1403/179; 4. JJ 3568/688; 5. JJ 3568/1032; 6. Kw 1403/ 327; 7. Kw $1403 / 492 ; 8$. JJ 3568/215; 9. JJ $3568 / 1014$; 10. JJ 3568/984.

Plate XVI

First row, from left to right: hollow rims from black-on-white painted vessels (5); outward-sloping rims of plain types (8); corrugated rims (4). Second row: triangular rims with flattened edge of a red-slipped type (4); outward-sloping rims of plain types (8); outward-sloping corrugated rims Third row: plain-type, outward-sloping rims.

Fourth row: plain-type, incurving and outward-sloping rims.

All these sherds belong to the De Josselin de Jong collection.

Plate XVII

I, notched ear on top of a plain-type rim. 2, specimen showing appliqué decoration. 3, foot of a single-legged bowl. 4, plain sherd with ridged decoration. 5, bottom of a tripod bowl, showing the points where the legs were fixed on the vessel wall. 6, red-slipped sherd with a knob. 7 , fabric-impressed sherd. 8, annular base of the black-on-red painted type. 9, probably a cover of a jar or a bottle; black-on-white painting with appliqué work.

I. JJ 3568/748; 2. JJ 3568/845; 3. JJ 3568/961; 4. JJ 3568/1003; 5. JJ 3568/983; 6. JJ 3568/951; r. JJ $3568 / 748$; 2. JJ $3568 / 845 ; 3$. J J $3568 / 961$;

Plate XVIII

I, hollow leg of a plain type. 2, hollow leg of the red-on-red painted type. 3 , low stand ring of plain vessel. 4, open annular base with support of the black-on-red painted type. 5, fragment of a single-legged plain bowl 6, typical incised sherd. 7, corrugated rimsherd, showing both ends of a coil. 8, frog motif on a black-on-tan painted sherd. 9, pottery disc. 1. Kw 1403/943; 2. JJ 3569/13; 3. JJ 3569/14; 4. JJ 3569/15; 5. Kw 1403/961; 6. JJ 3569/16;
7. JJ 3569/17; 8. Kw 1403/980; 9. JJ 3569/18.

Plate XIX

I, black-on-white. 2, black-on-red. 3, 4 and 8, black-on-tan. 5, 6 and 7 , polychrome painting; black and red-on-white. 9, fragment of an open annular base with polychrome painting like the preceding. Io, handle fragment; black and red-on-red painting.

I. JJ 3569/19; 2. JJ 3569/20; 3. JJ 3569/21; 4. JJ 3569/22; 5. JJ 3569/23; 6. Kw 1403/957; 7. JJ $3569 / 24$; 8. JJ 3569/25; 9. JJ 3569/26; 10. JJ 3569/27.

Plate XX

I, 2 and 5 , ears on plain-type pottery sherds. 3, ear on a red-slipped pottery sherd. 4 , griddle fragment. 6 , bird's head adorno on a red-slipped pottery fragment. 7 , plain handle.

I. JJ 3569/28; 2. JJ 3569/29; 3. JJ 3569/30; 4. JJ 3569/31; 5. JJ 3569/32; 6. JJ 3569/33; 7. JJ $3569 / 34$. 


\section{Plate XXI}

I, corrugated rimsherd. 2, plain sherd with appliqué decoration. 3, perforated annular base. 4, pottery disc. 5, black-on-white painted sherd 6 , round bottom, inside view. 7, solid leg. 8, fragment of a zoomorphic (turtle?) leg. 9, griddle fragment. Io, red-on-tan painted sherd. II, redon-white painted sherds.

I. WH $3638 / 2$; 2 . WH $3638 / 3 ; 3$. WH $3638 / 4 ; 4$. WH $3638 / 5 ; 5$. WH $3638 / 6 ; 6$. WH $3638 / 7$; 7. WH $3638 / 8$; 8. WH $3638 / 9$; 9 . WH $3638 / 10$; 10 . WH $3638 / 11$; 11 . WH $3638 / 12$.

\section{Plate XXIIa}

Frog motive in appliqué work on a black-on-red painted sherd.

$$
\text { JJ } 3568 / 508
$$

\section{Plate XXIIb}

I, Shell amulet (Strombus gigas); St. Jan, Curaçao. 2, Three-pointer (Strombus gigas); St. Jan, Curaçao.

I. JJ 3569/11; 2. JJ 3569/10.

\section{Plate XXIII}

I, Shell gouge; Santa Cruz, Aruba. 2, Modified shell gouge; Aruba. 3. Shell celt; Westpunt, Curaçao. 4, Shell plate; Aruba. 5, Shell plate; Santa Cruz, Aruba. 6 and 7, Shell discs; Aruba.

1. JJ 3568/1023; 2. JJ 3568/478; 3. Kw 1403/869; 4. JJ 3568/488; 5. Kw 1403/44; 6. JJ 3568/489; 7. JJ $3568 / 690$.

\section{Plate XXIV}

I, Fragment of a nose ring; Santa Cruz, Aruba. 2, Buttonlike object; Asiento, Curaçao. 3, Disc; Aruba. 4, Shell bead with a hole pierced in the centre; Aruba. 5, Shell bead; Aruba. 6, Amulet; Aruba; 7. Small ring; Asiento, Curaçao. 8, Bead; Asiento, Curaçao. 9, Whole bead (Amphiperas cyphoma gibbosum L.); Asiento, Curaçao. Io, Whole shell bead (Amphiperas cyphoma gibbosum L.); Asiento, Curaçao. II, Ear-plug: Asiento, Curaçao. I2, Stone bead (quartzite); Asiento, Curaçao. 13, Bead (Ostrea sp.); Asiento, Curaçao. 14, Shell pendant; Asiento, Curaçao. I5, Pendant (Oliva sp.); Aruba. 16, Ear-plug; Aruba.

1. JJ 3568/656; 2. JJ 3568/1028; 3. JJ 3569/r; 4. JJ 3568/691; 5. JJ 3568/496; 6. Kw 1403/371/ 7. JJ 3569/2; 8. J J 3569/8; 9. JJ 3569/4; 10. JJ 3569/6; II. JJ 3569/7; I2. JJ 3569/3; 13. JJ $3569 / 9$; 14. JJ $3569 / 12$; 15. JJ 3568/491; 16 . Kw $1403 / 538$.

\section{Plate XXV}

I, Petaloid stone celt; Bonaire. 2, Long, narrow chisel; Bonaire. 3 'Blank'; Aruba. 4, Unfinished stone celt with ground bit; Aruba; 5, Stone celt; Santa Cruz, Aruba. 6, Polished knife; Aruba. 7, Slingstone; Aruba. 8, Flat stone axe; Bonaire. 9, Pygmy chisel (nephrite); Curaçao. Io, Pygmy chisel; Bonaire. I I, Pygmy chisel; Aruba.

1. Kw $1403 / 769$; 2. Kw $1403 / 791$; 3. JJ 3568/468; 4. JJ 3568/476; 5. JJ 3568/466; 6. Kw 1403/ 667 ; 7. JJ 3568/1023; 8. JJ 3568/466; 9. Kw 1403/859; 10. Kw 1403/793; 11. Kw 1403/34

\section{PLATE XXVI}

I, Amulet made of turtle bone; Santa Cruz, Aruba. 2, Spatula made of turtle bone; Santa Cruz, Aruba. 3, Bone point; Santa Cruz, Aruba.

JJ 3568/685; 2. JJ 3568/682; 3. JJ 3568/102r. 


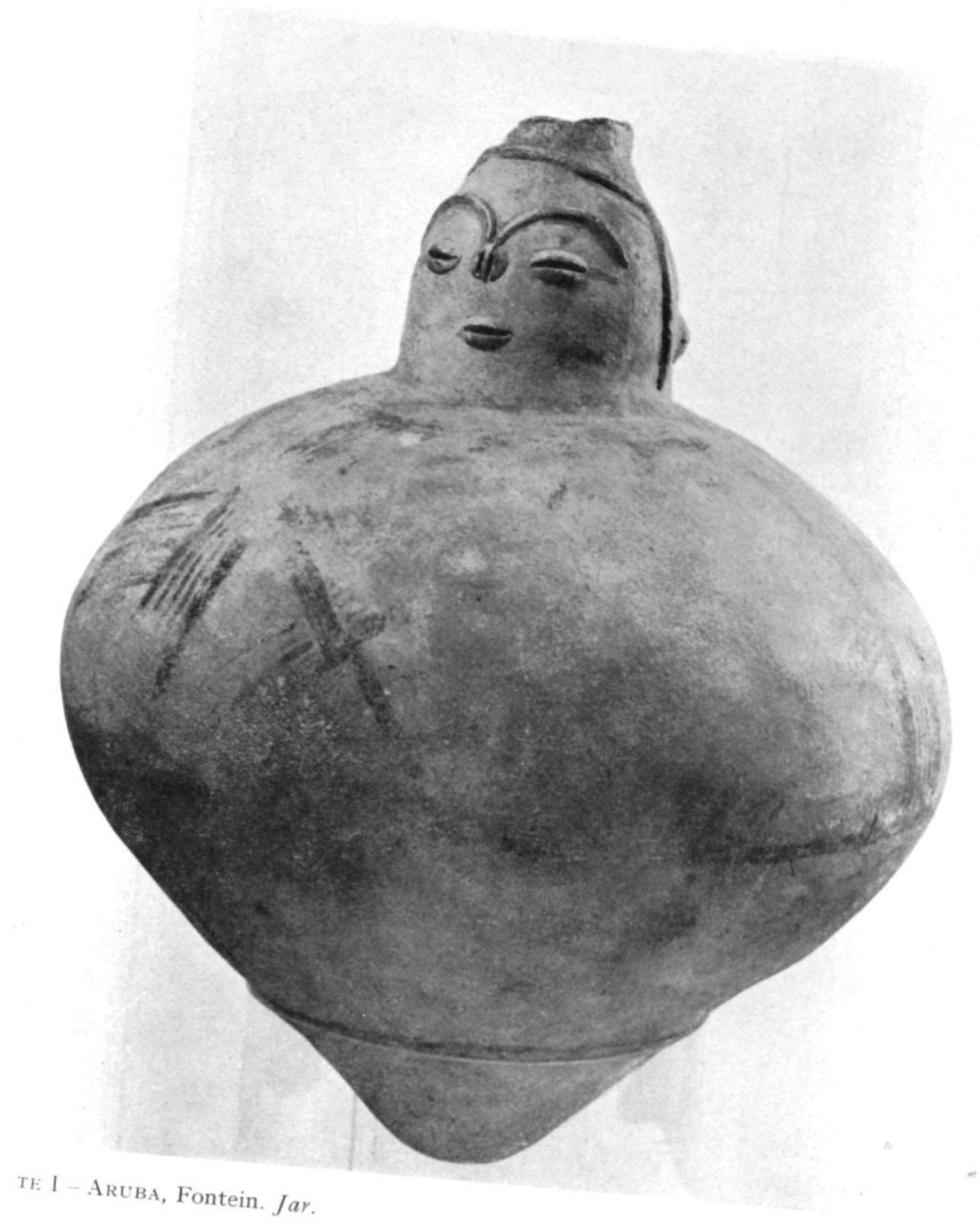




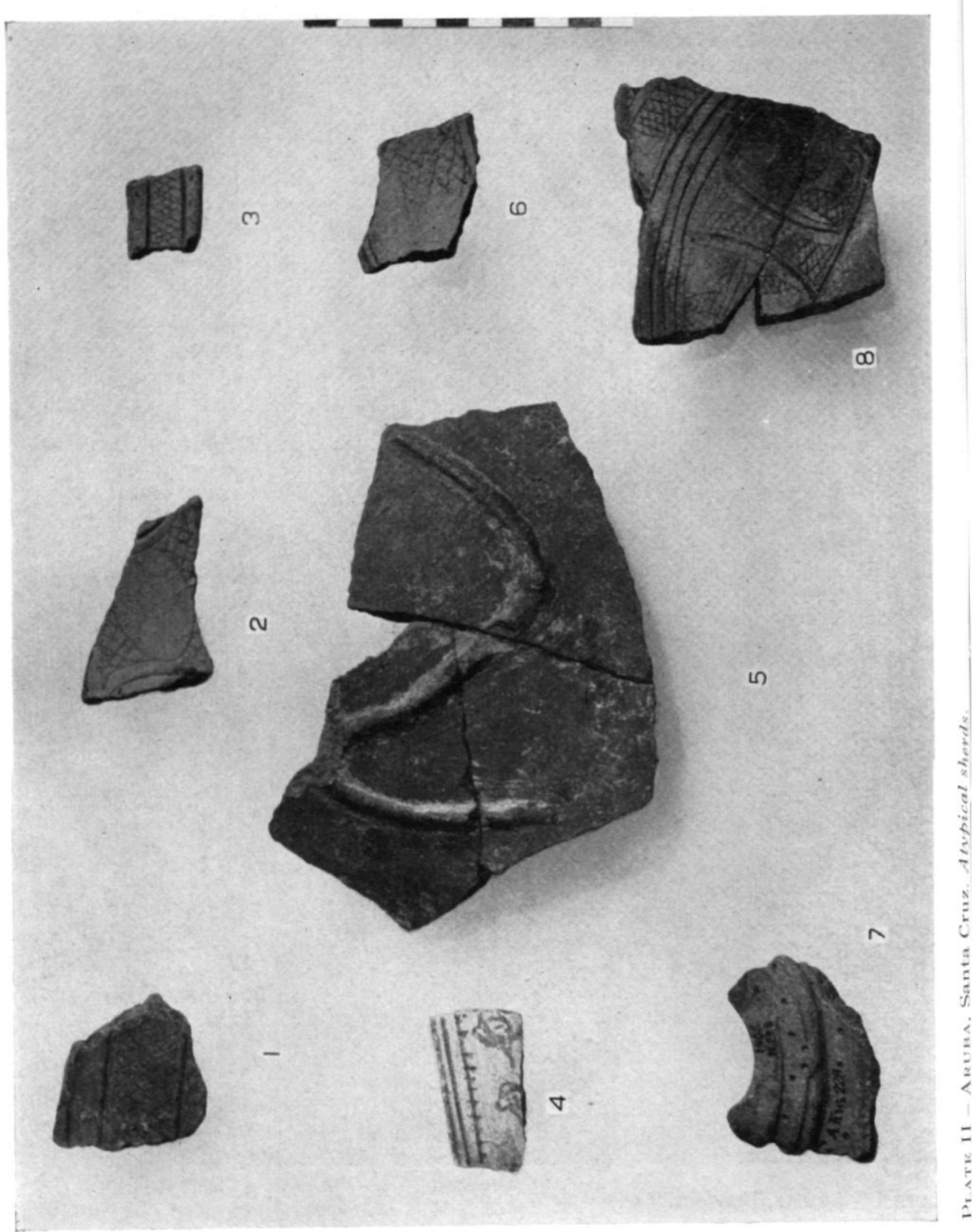




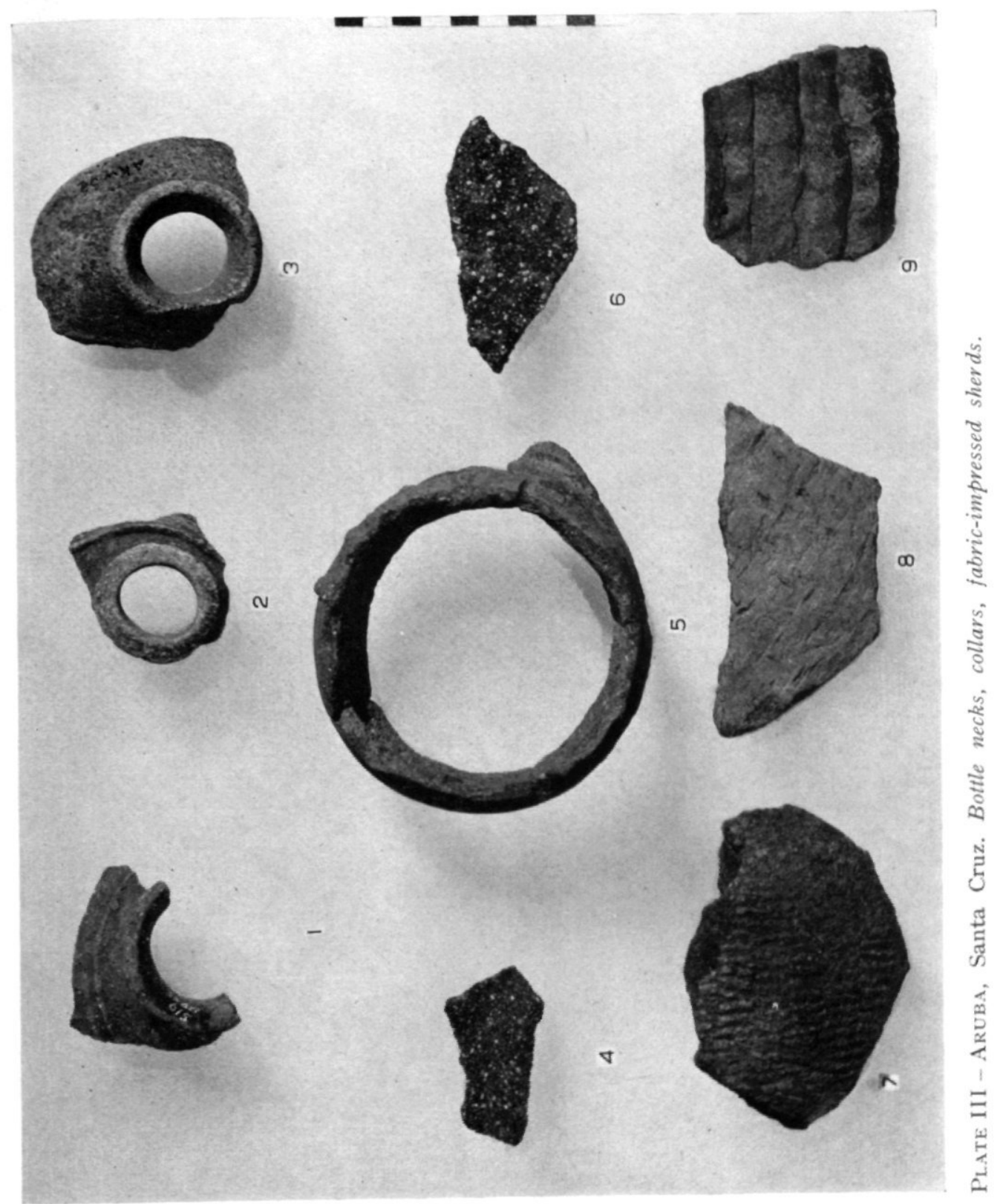




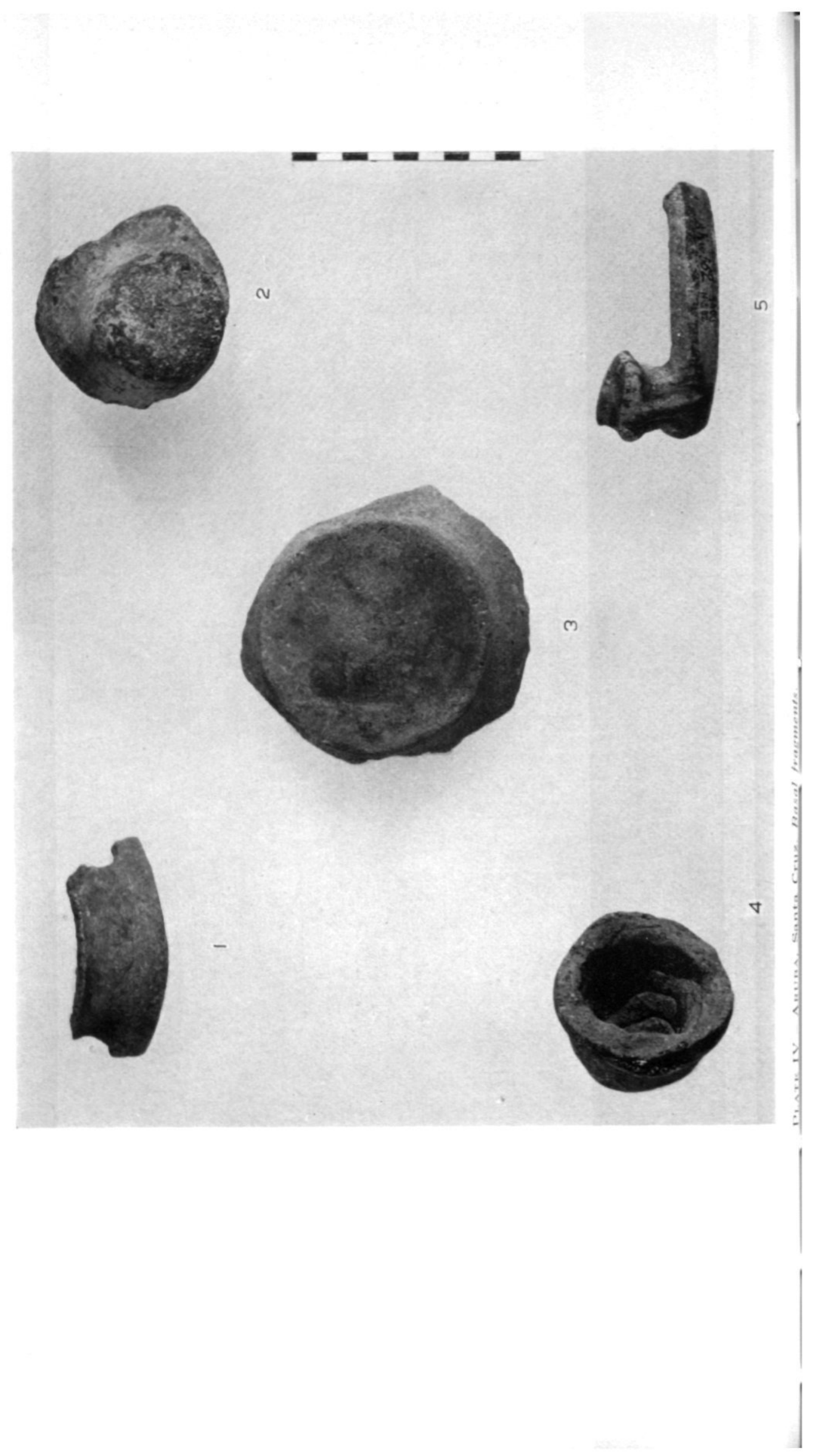




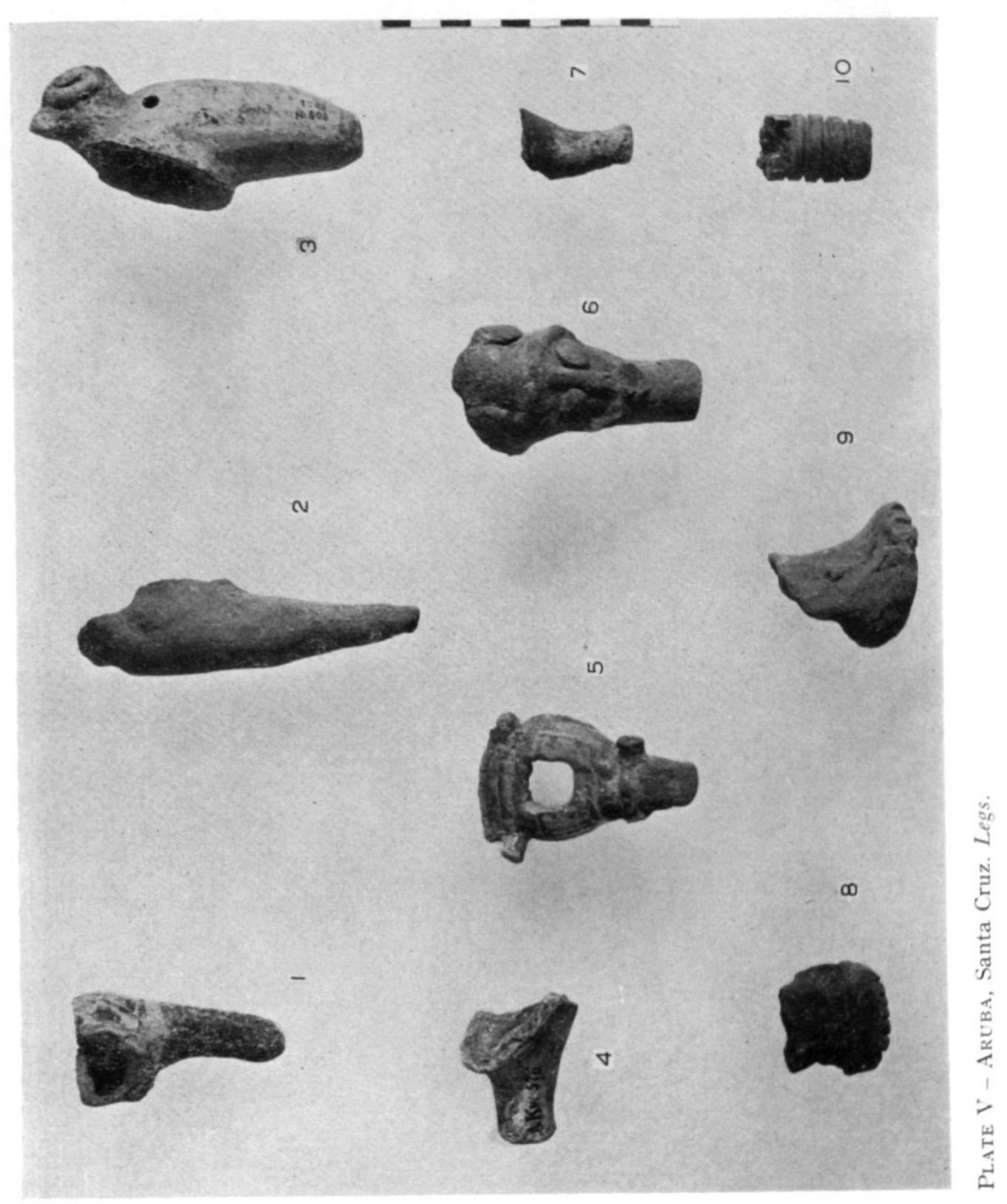




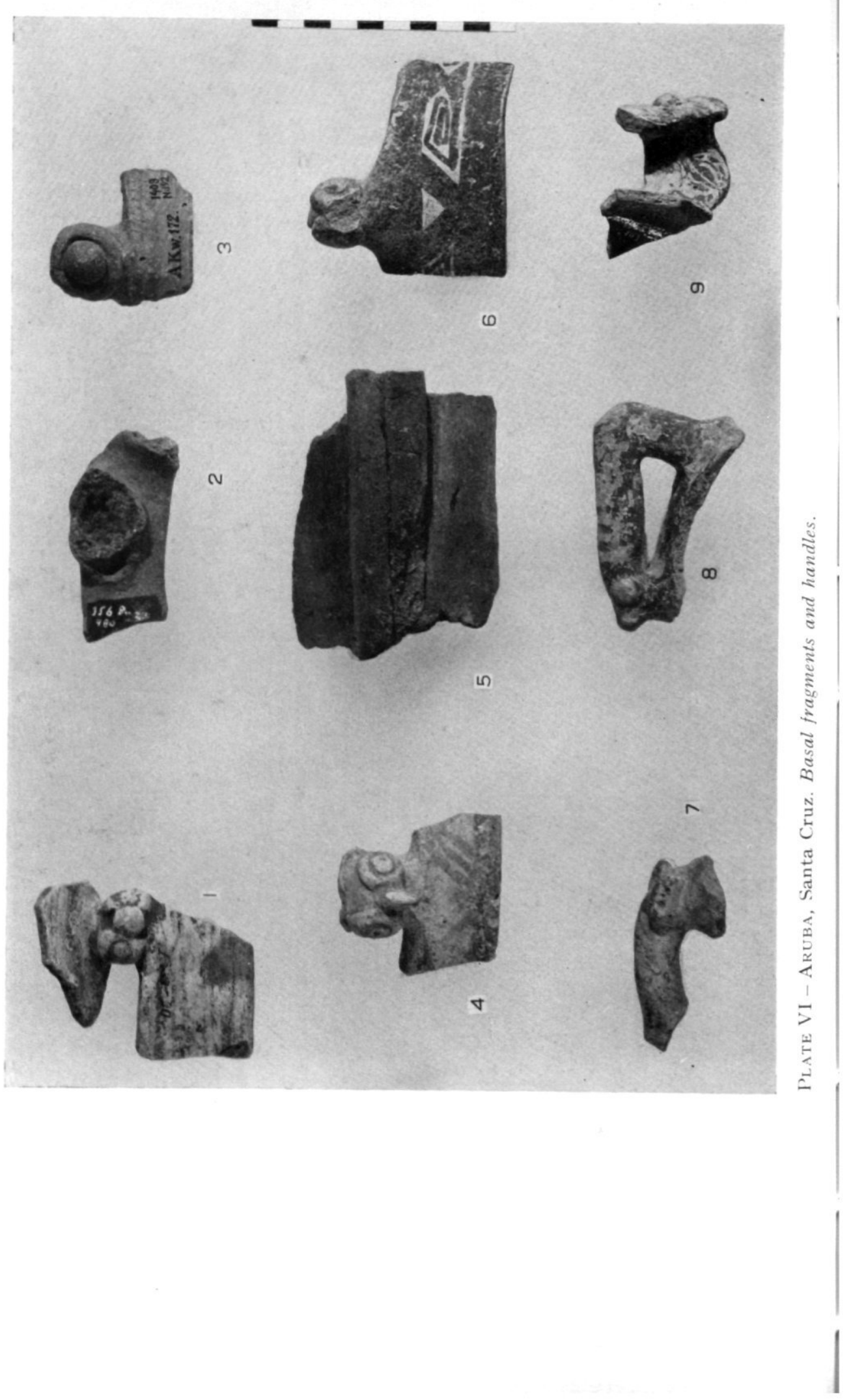




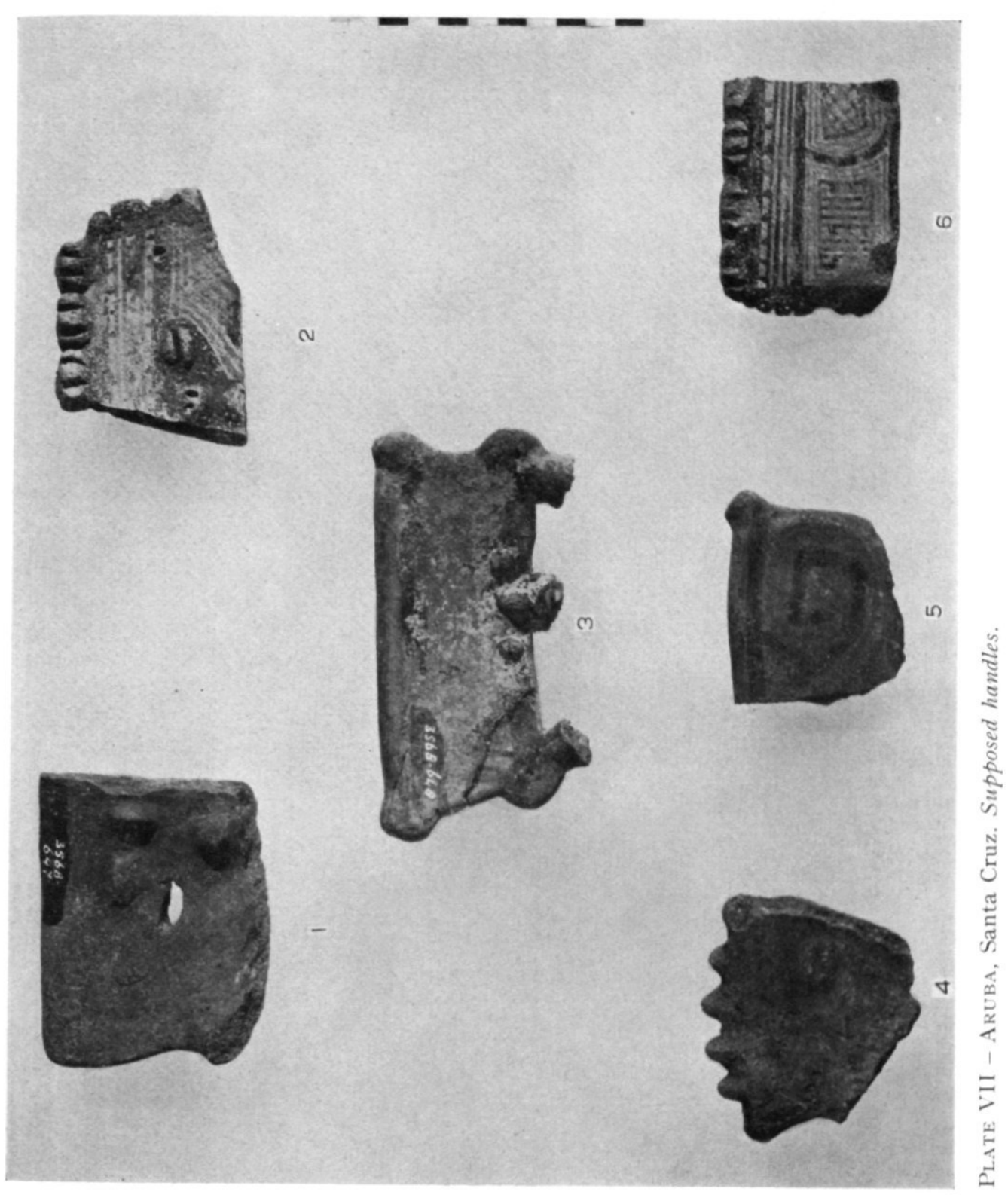




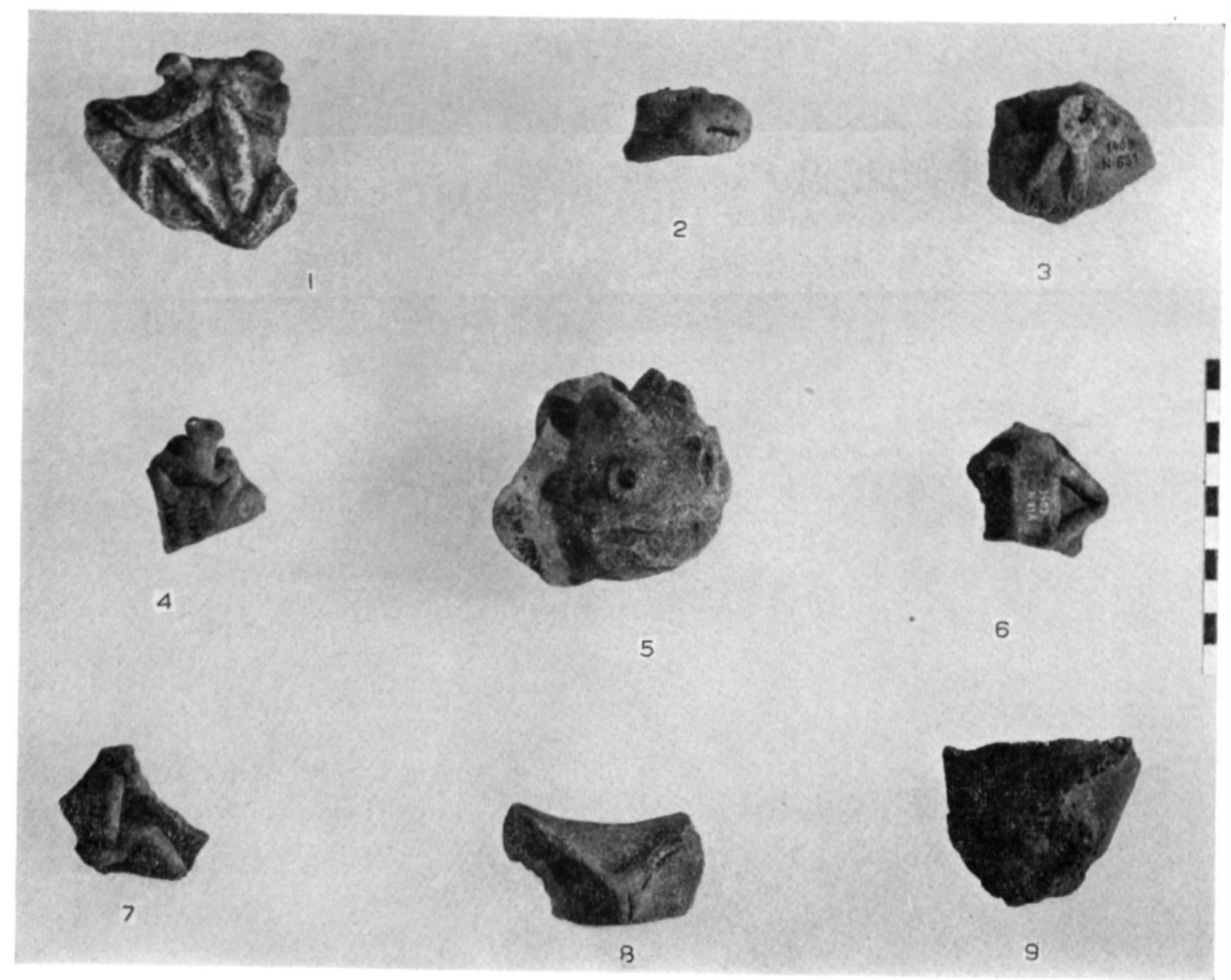

Plate X - Aruba, Santa Cruz, Z'oomorphic features. 


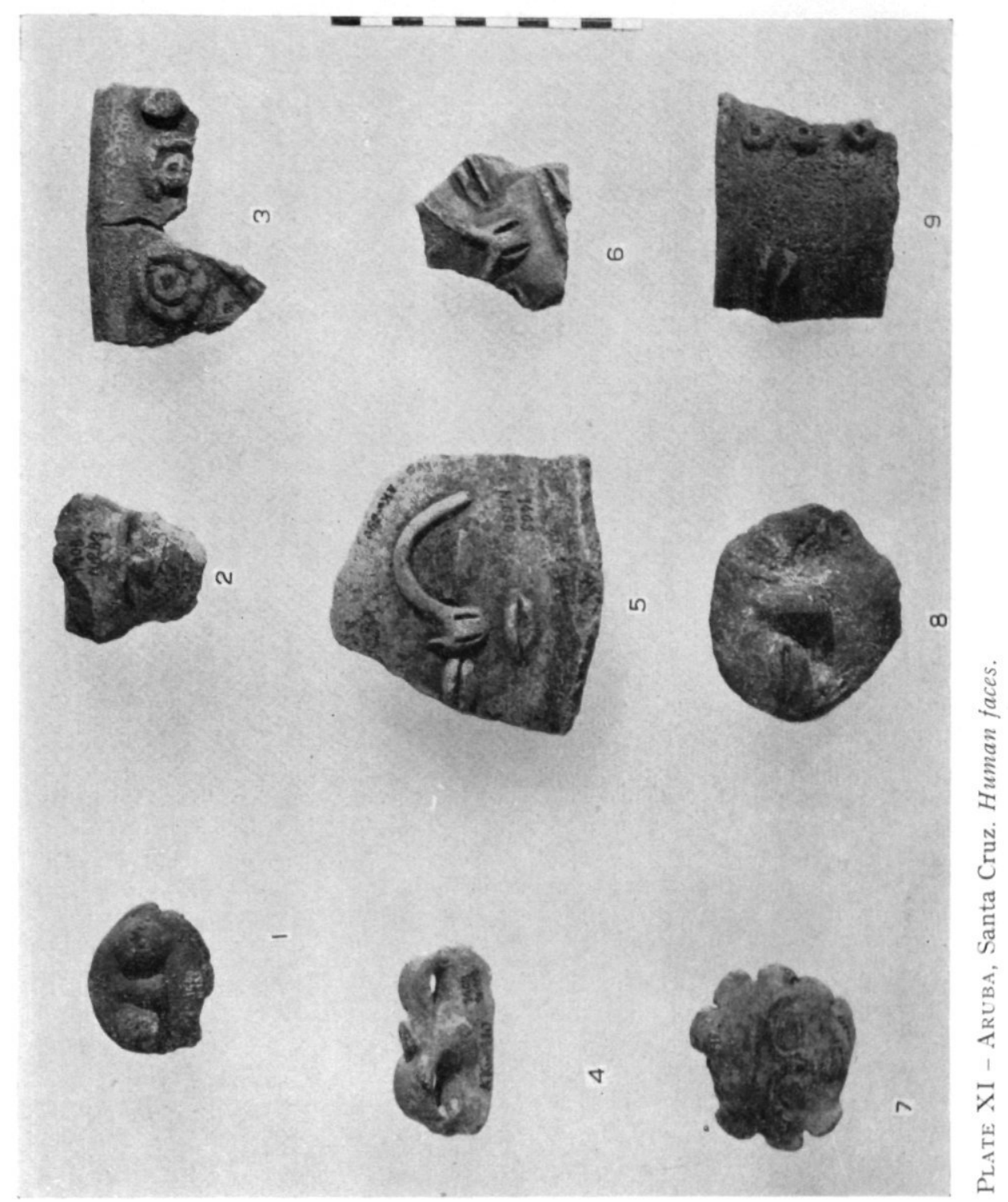




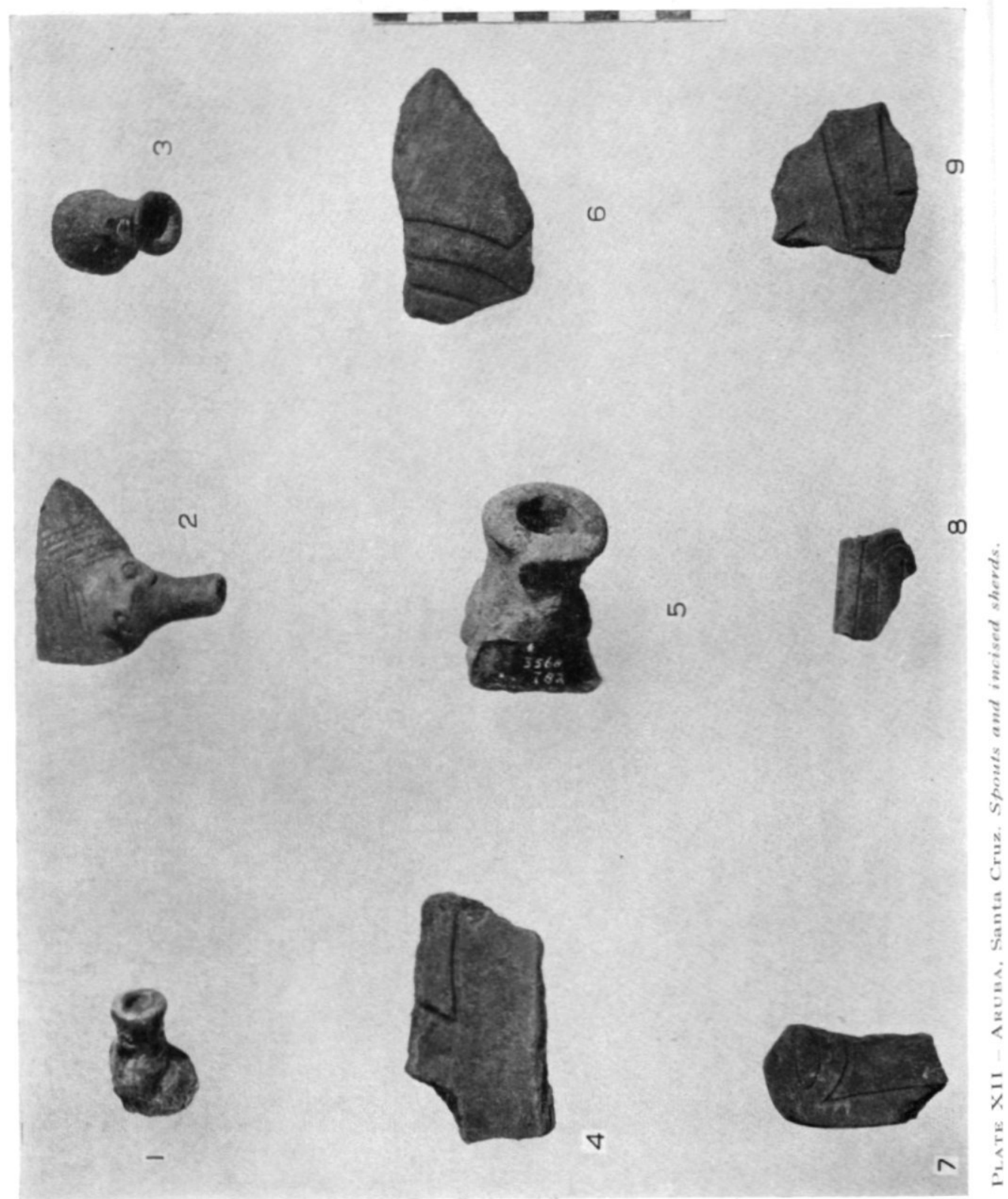




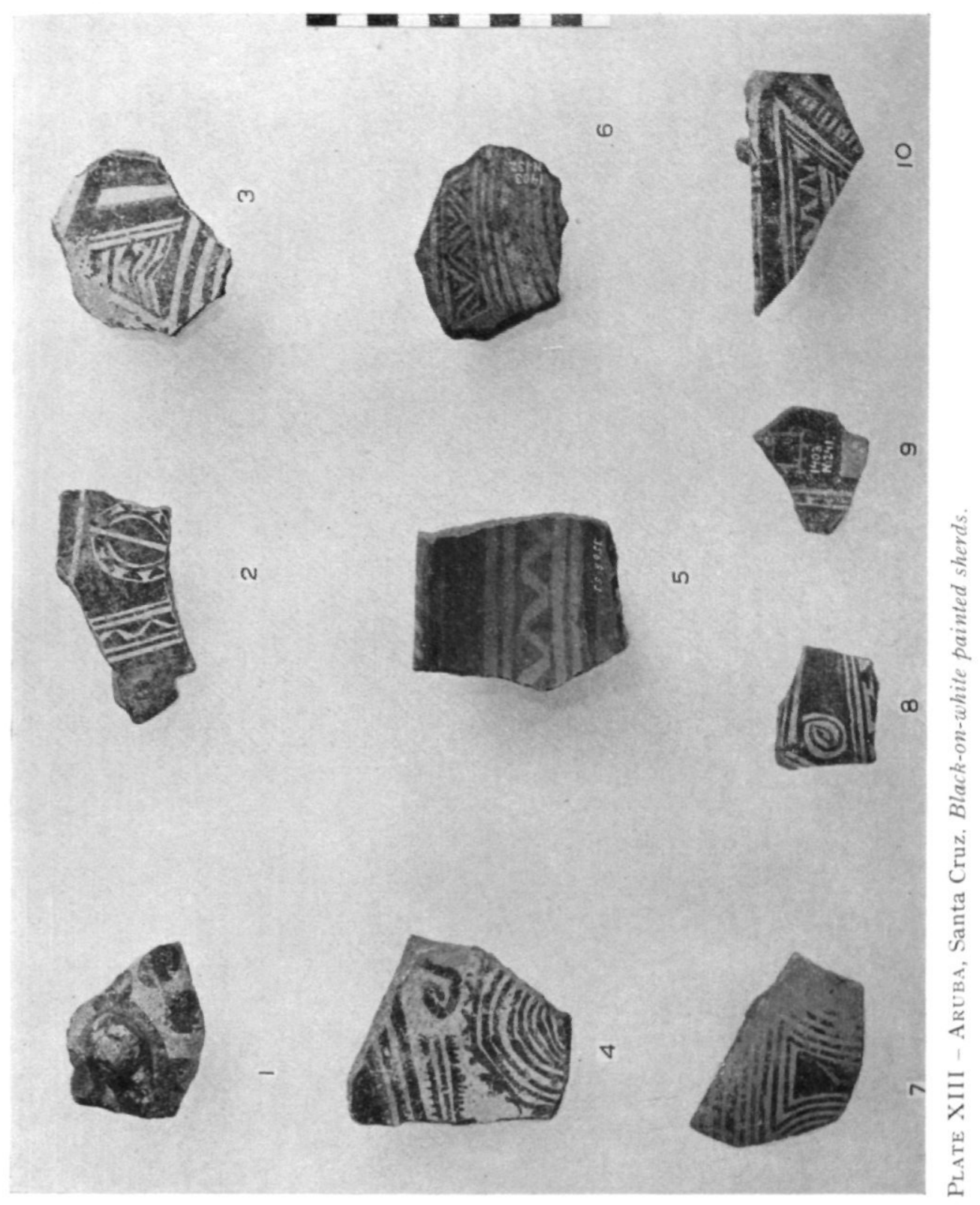




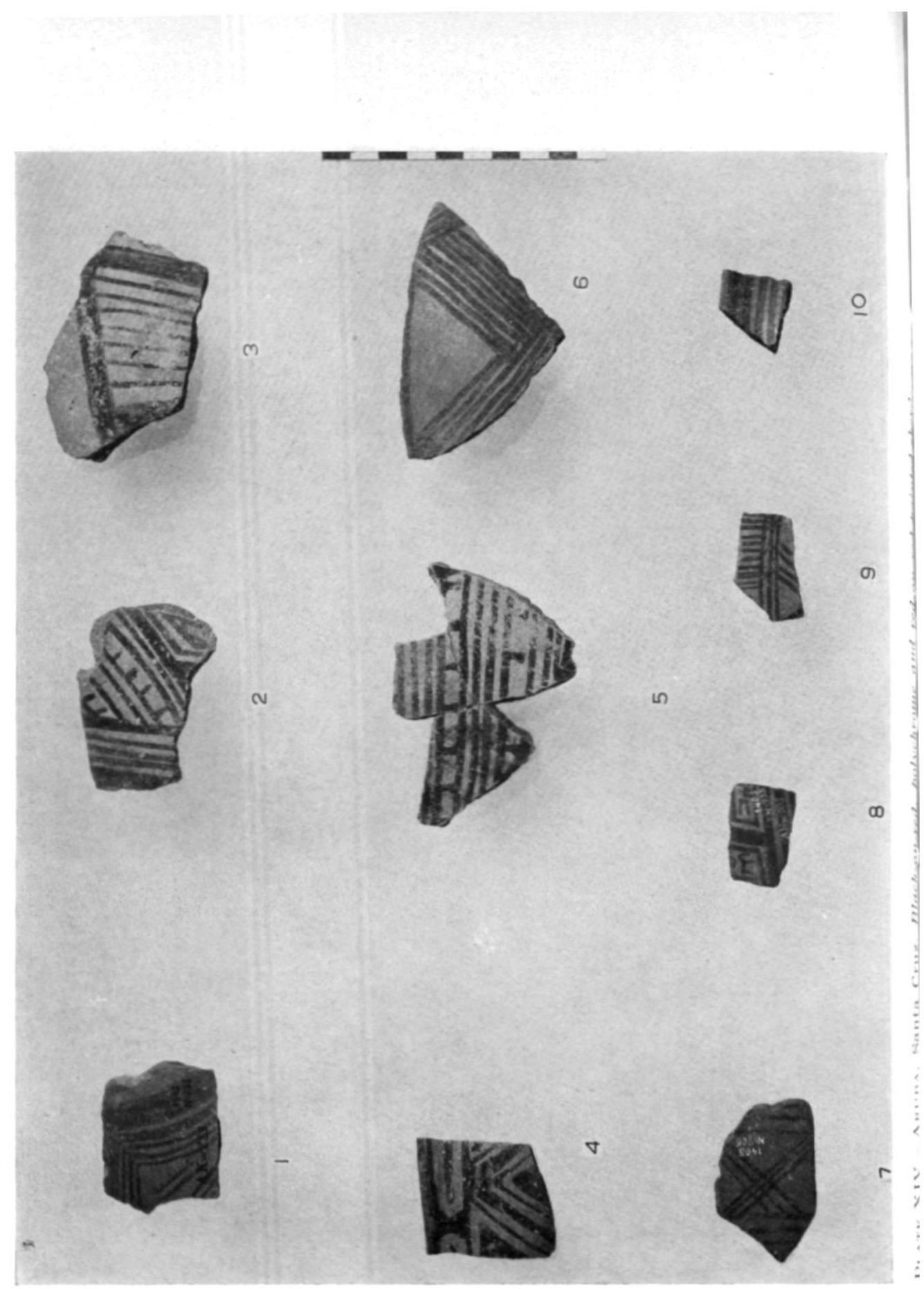




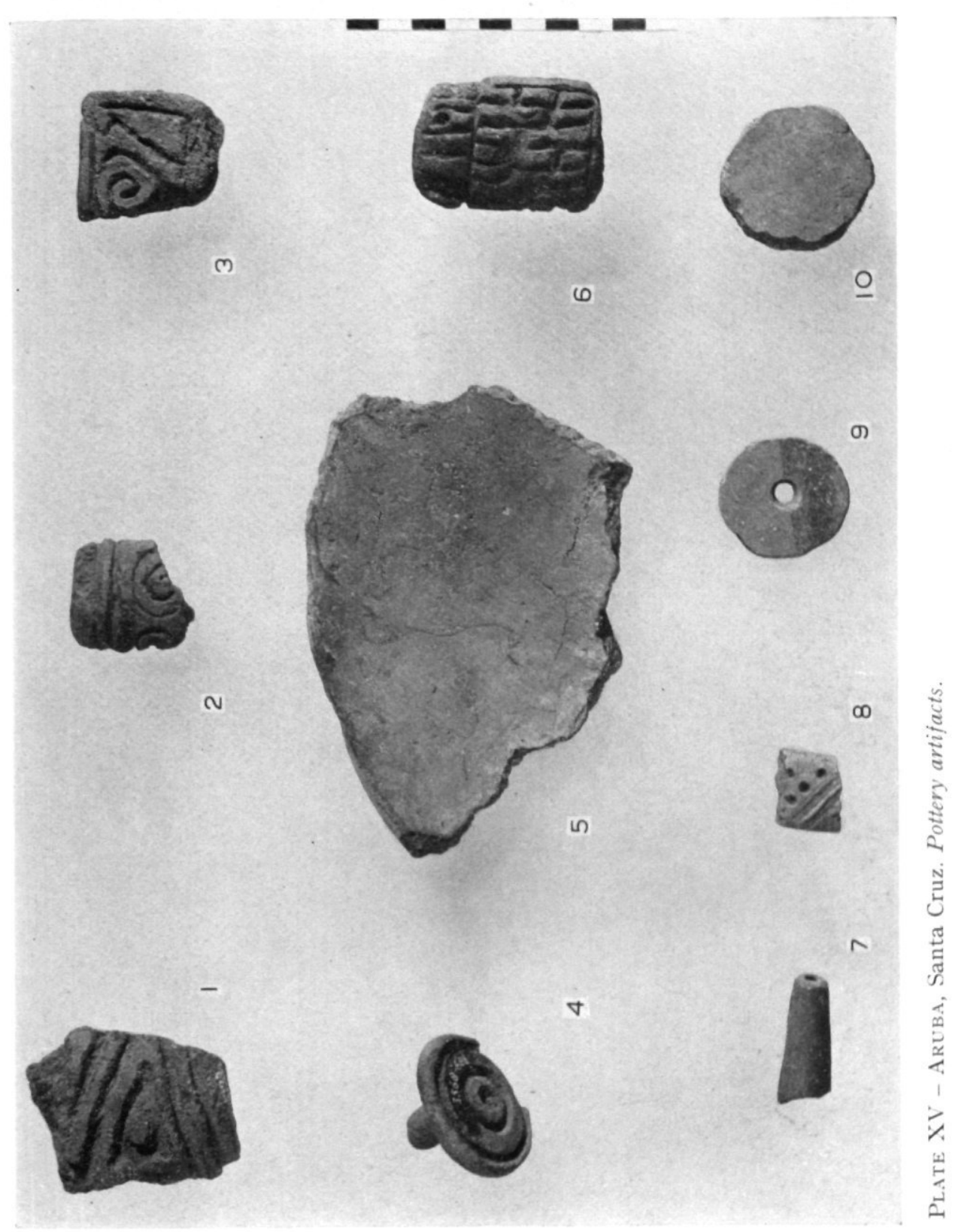




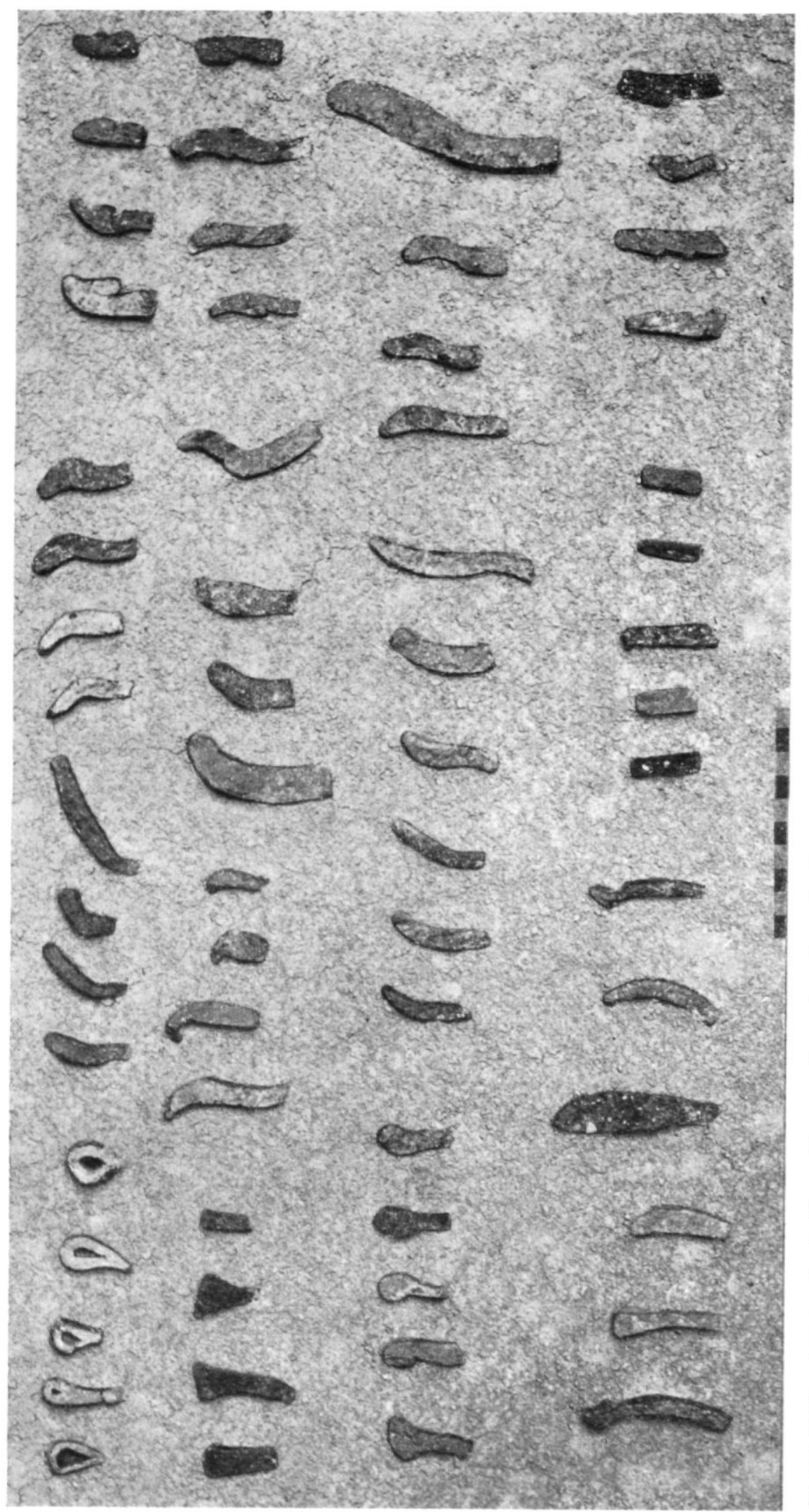




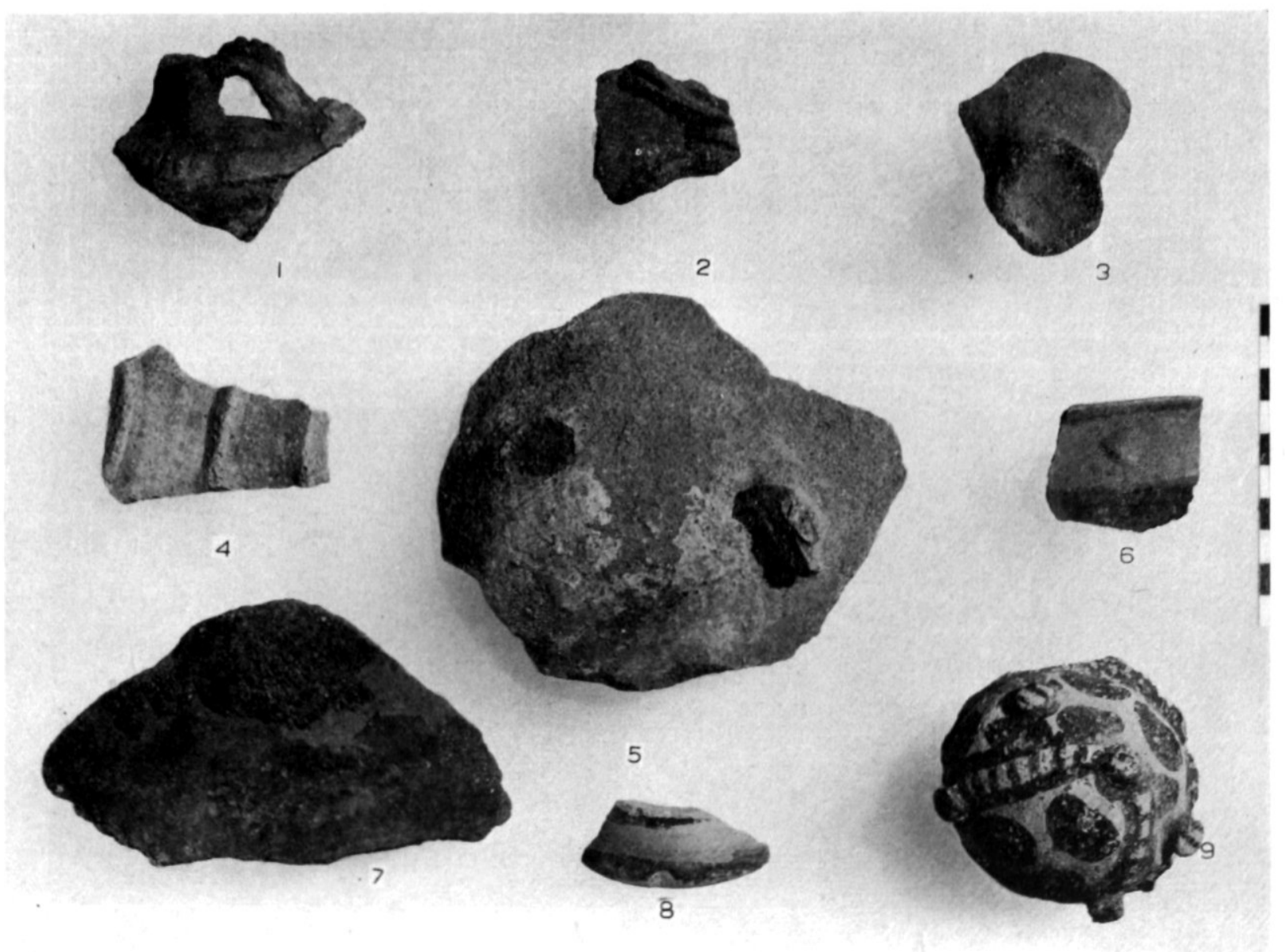

Plate XVII - Aruba, Savaneta. Miscellaneous sherds. 


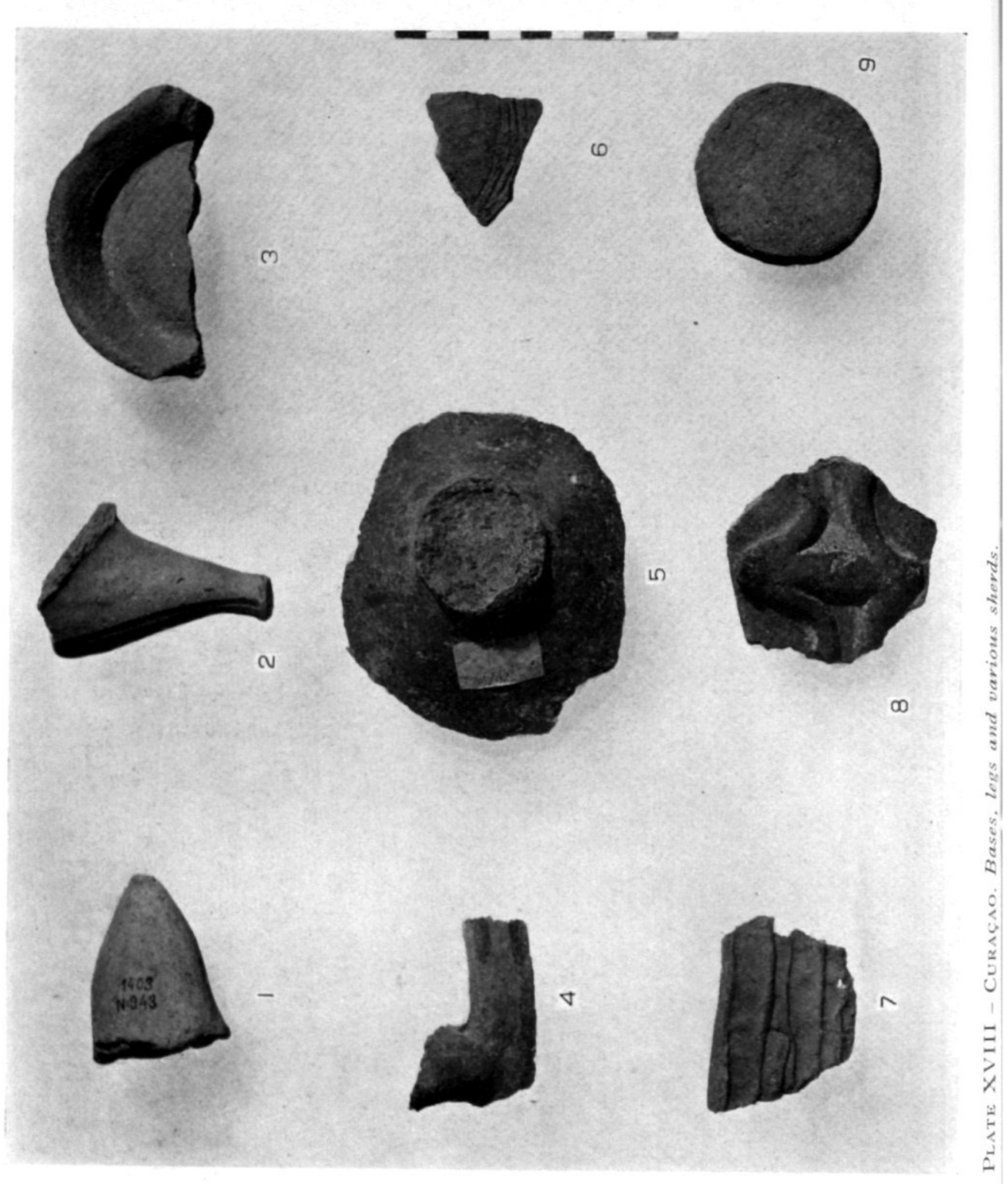




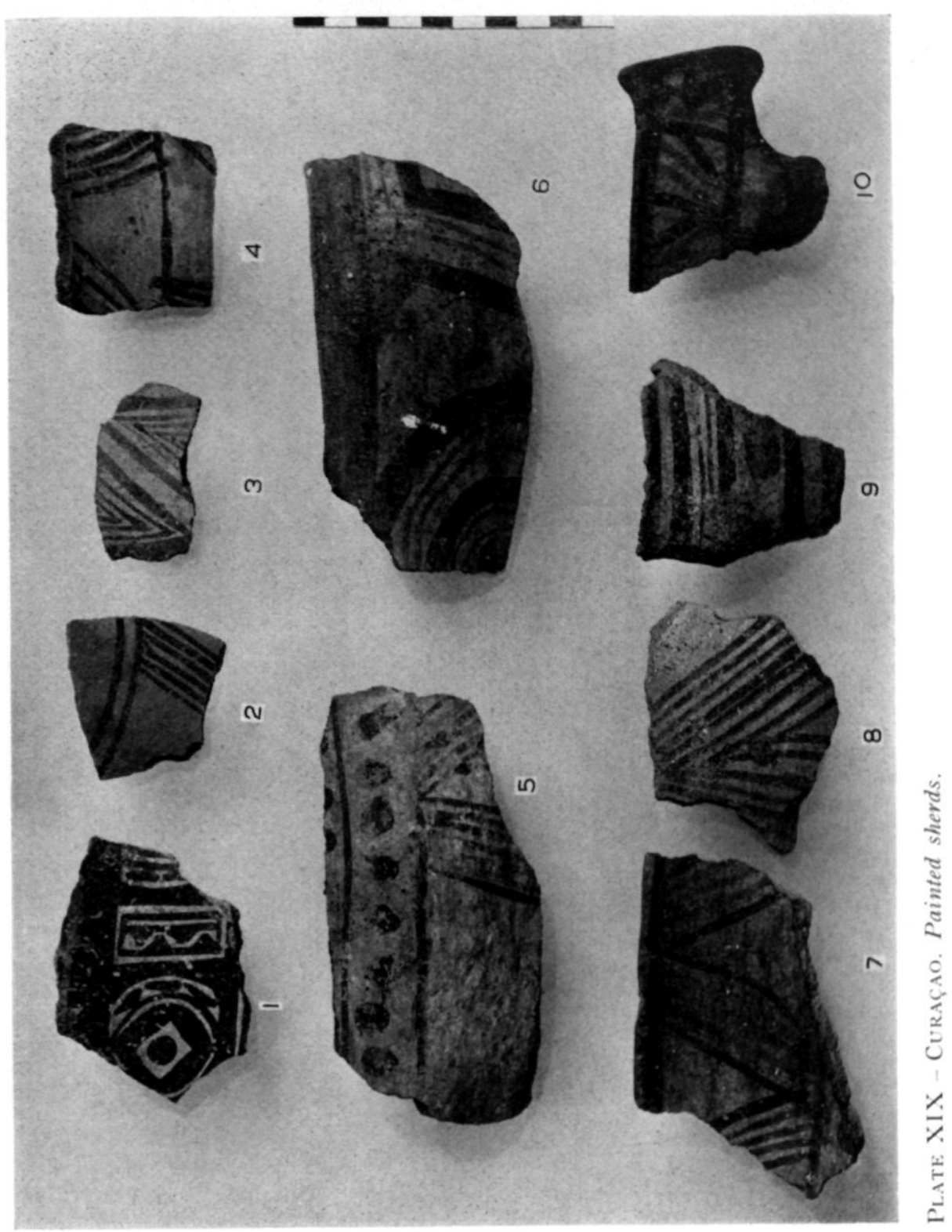




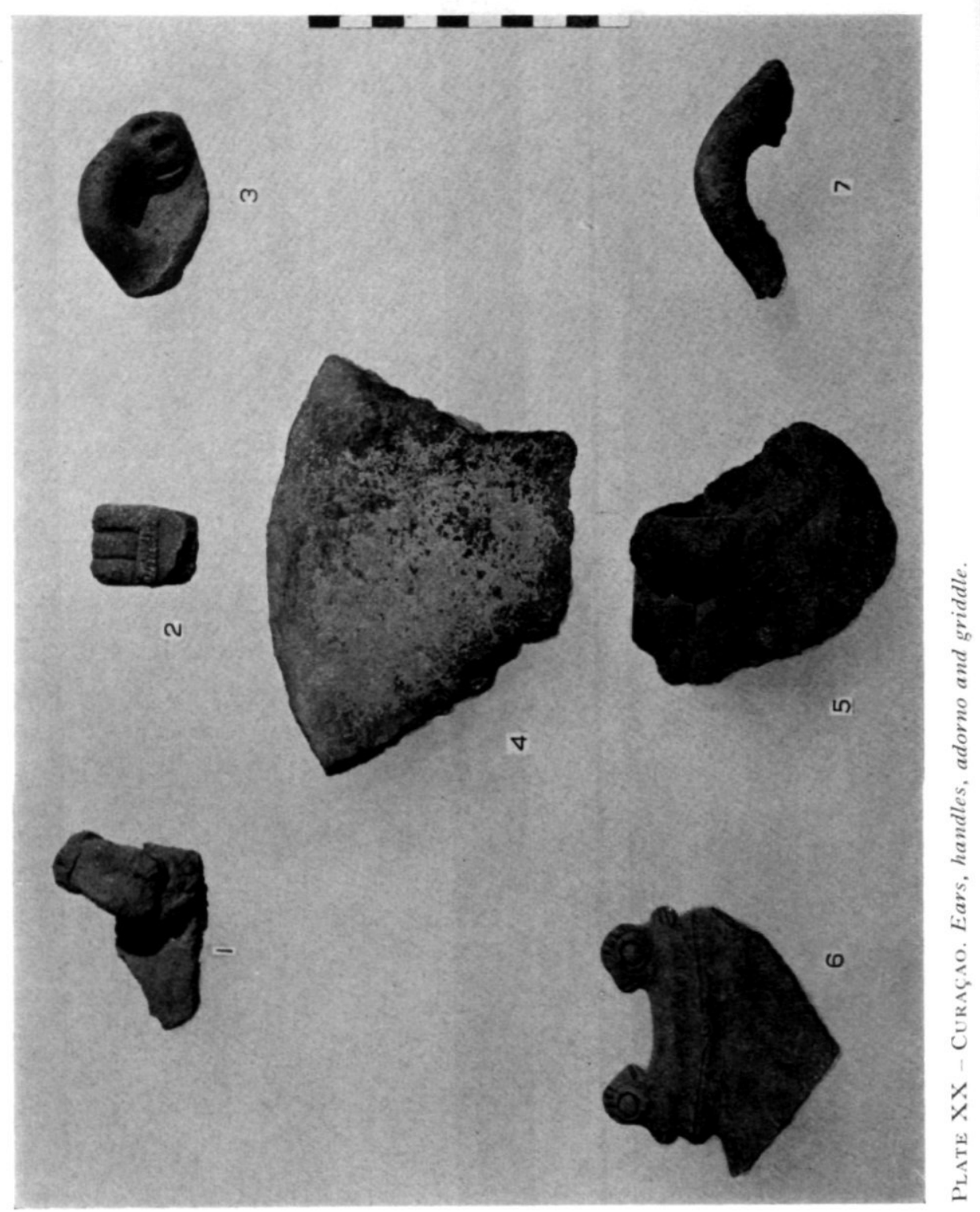




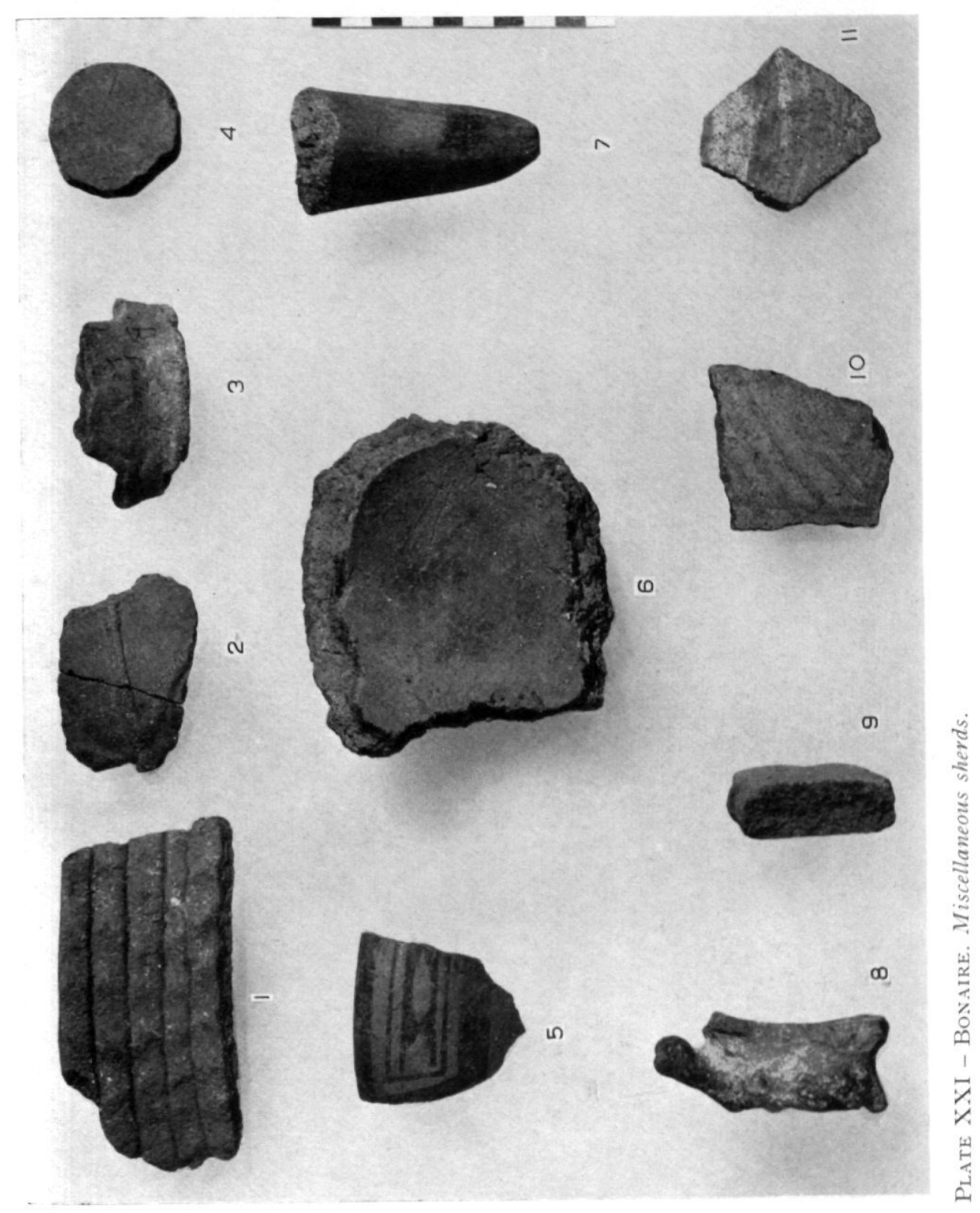




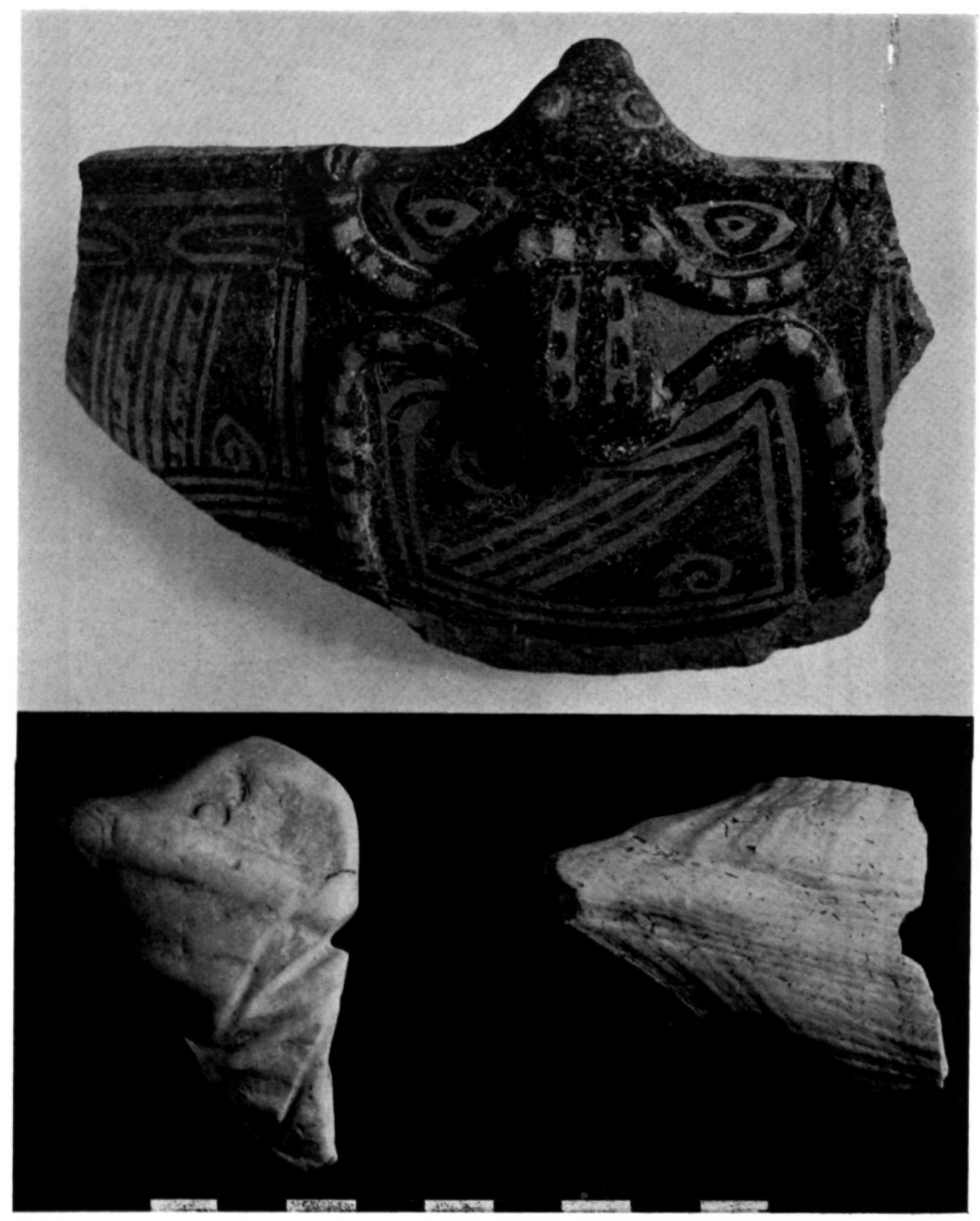

Plate XXila - Aruba, Santa Cruz. Zoomorphic feature.

Plate XXIIb - Strombus Points. Curaçao. 


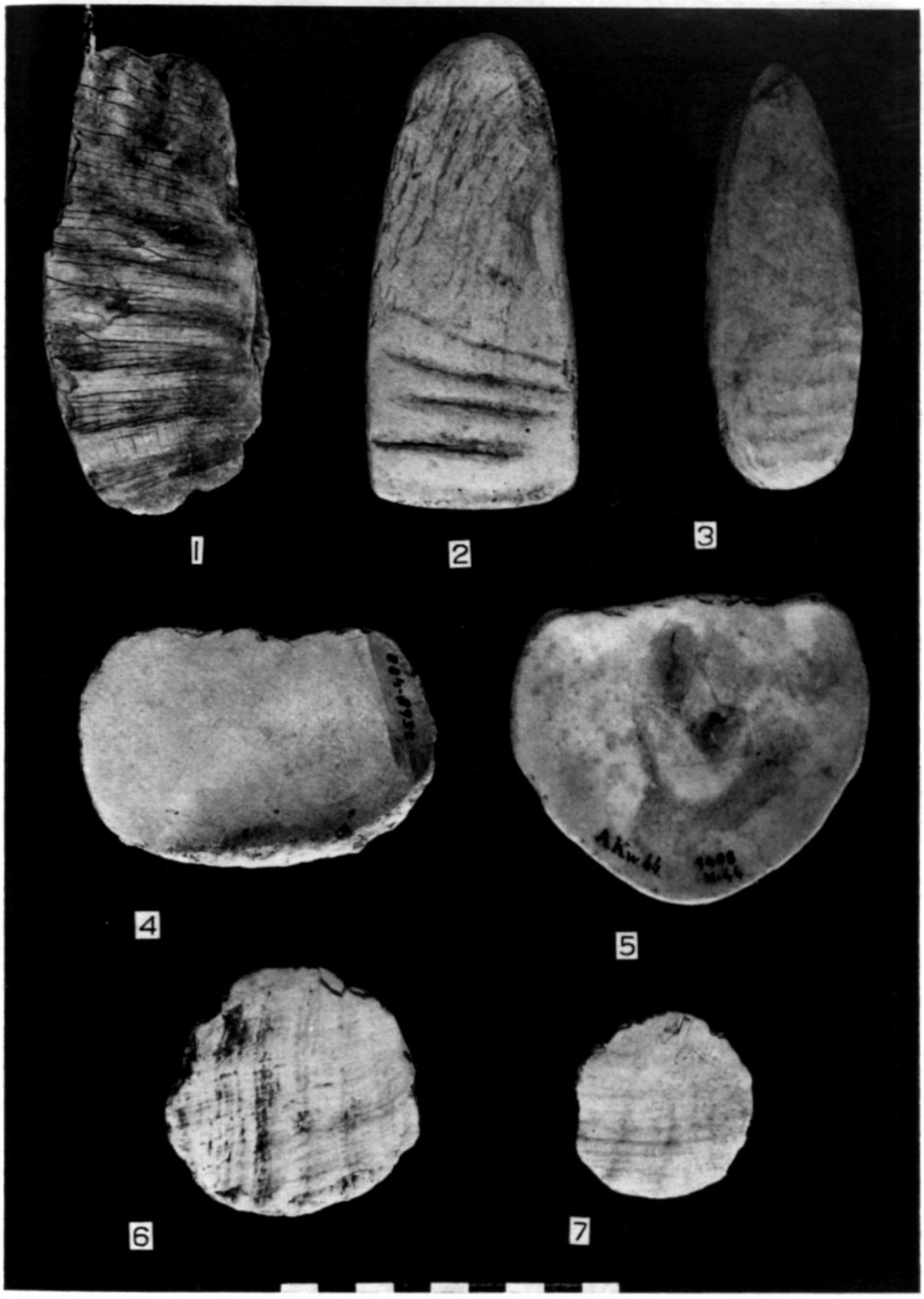

Plate XXili - Typical Shell Artifacts. Aruba, Curaçao. 


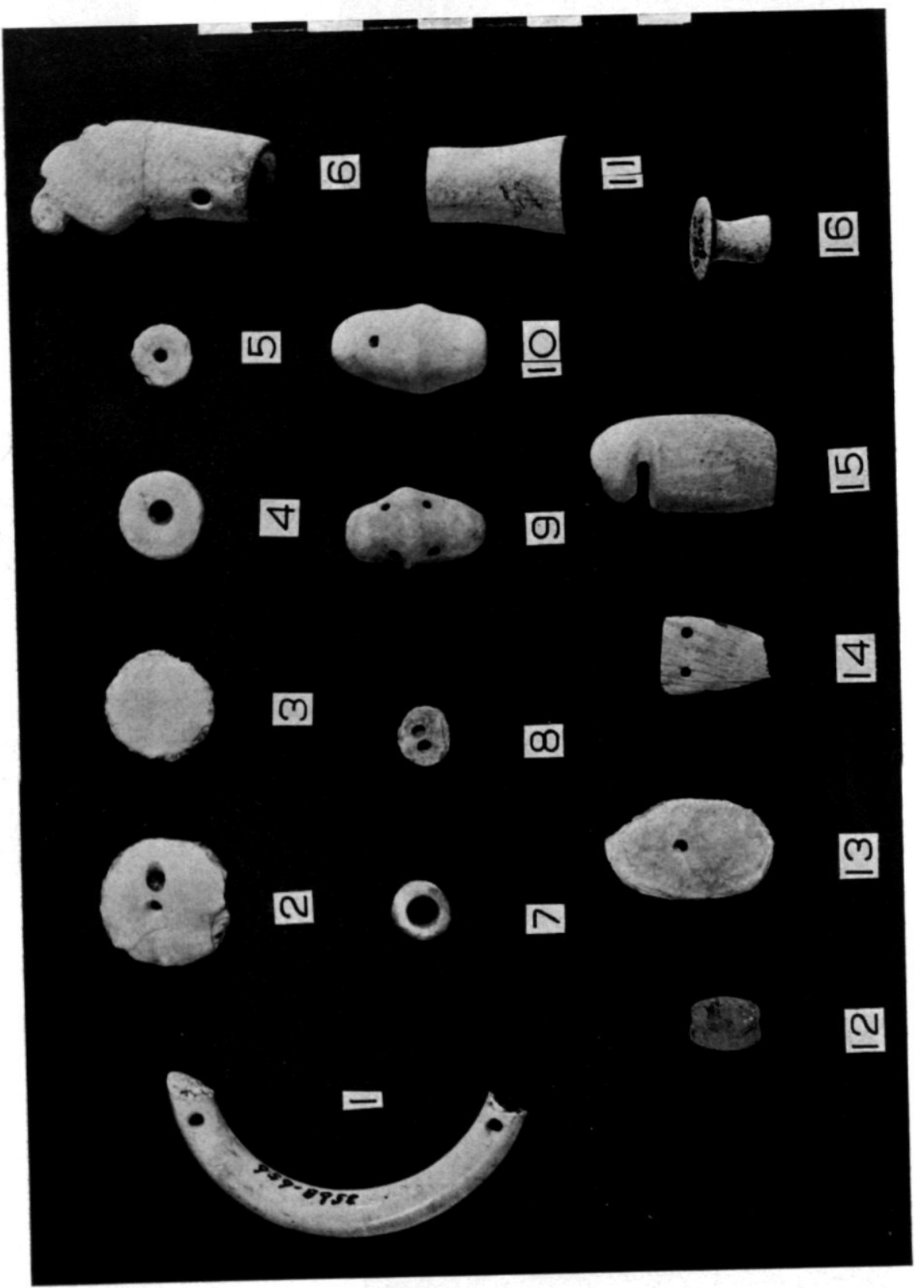

Plate XXIV - Shell Ornaments. Aruba, Curaçao. 


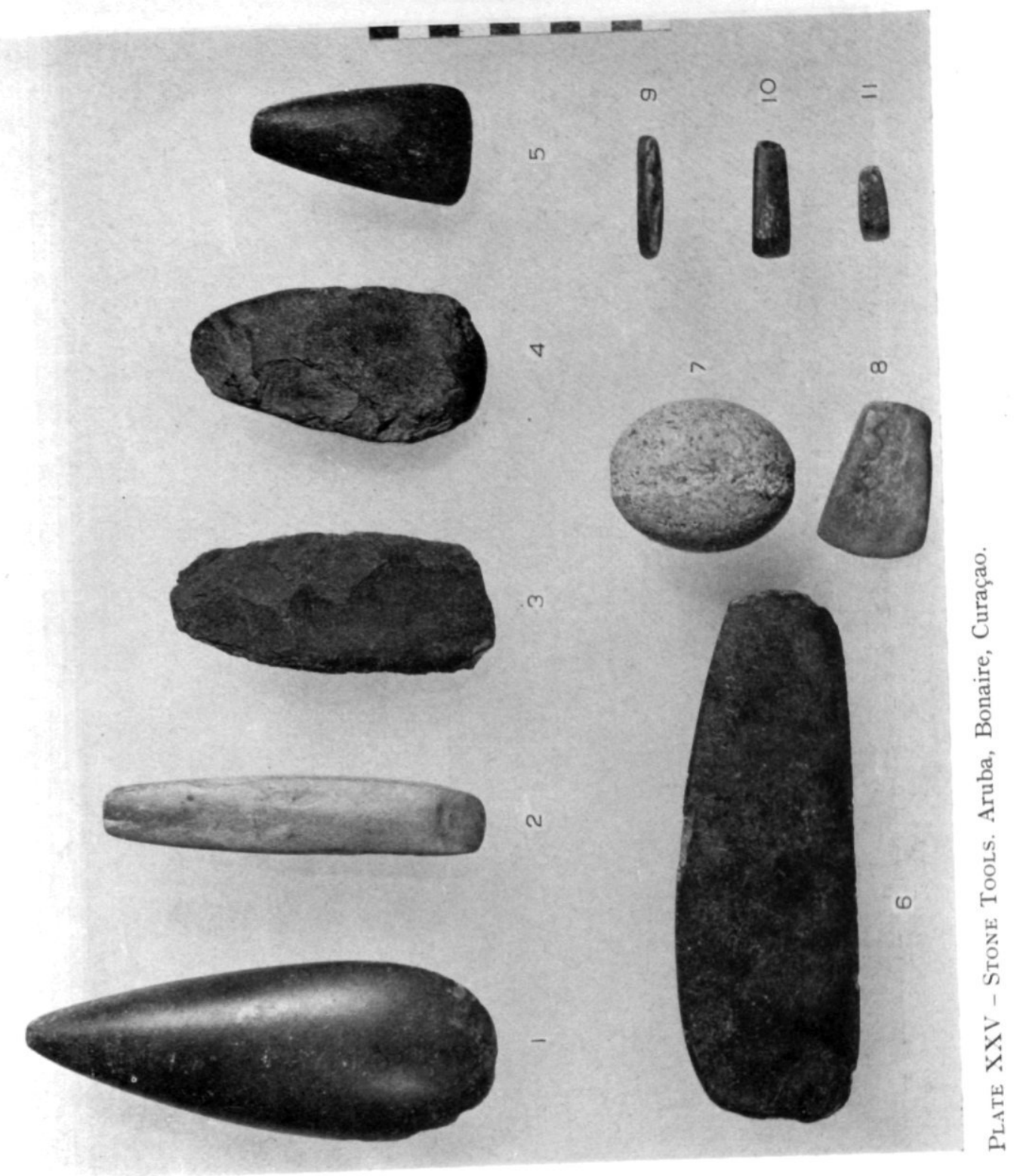




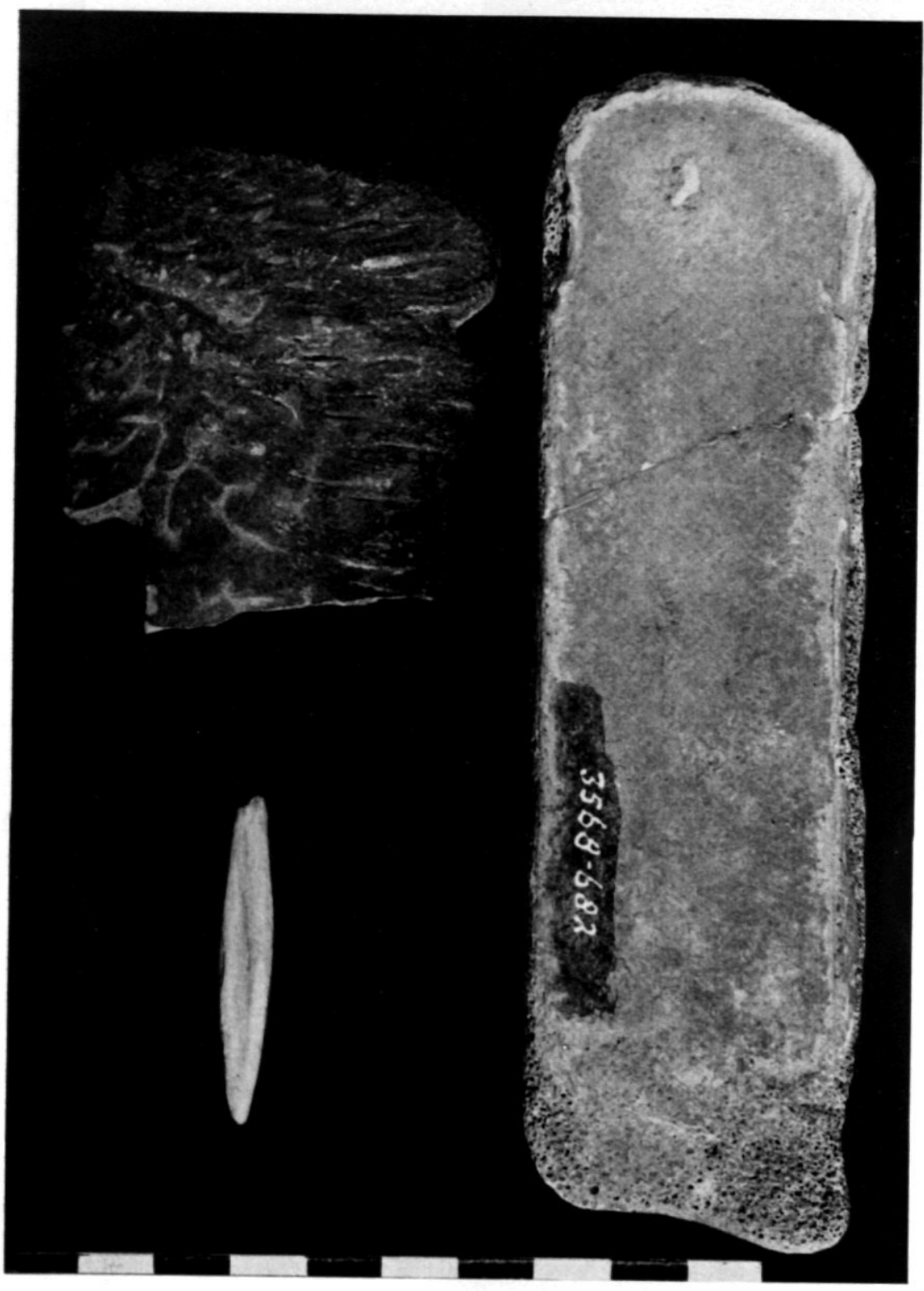

Plate XXVi - Bone Implements. Aruba. 
Numerous larger and smaller shell tips, also called threepointers or Strombus tips, are found in Aruba and Curaçao; these simple tools were probably used in extracting the meat from shells, or for piercing or drilling (Pl. XXIIb, 2). Noteworthy is a large three-pointer, the lower part of which carries an engraving in straight lines of a conventionally stylized frog design (Pl. XXIIb, I). In style and workmanship this specimen resembles the Andean stone figures, and it could also be classified with the shell ornaments from Tocorón (OsGood, I943, fig. IIm. KIDDER, I944, p. I37-I38, figs. 60 \& 62). DE JosSELIN DE JoNG (I924, p. 43-45) has his own opinion about the shell threepointers. He regards them as natural prototypes of the carved anthropomorphic deities of Cuba and Puerto Rico, called 'zemi' which were supposed to promote the fertility of vegetable crops.

\section{Stone ArTifacts}

The most distinctive tools under this heading are stone celts of various types, and I shall describe them in some detail. Most celts are rather small and broad, without parallel sides and with a narrow butt-end, trapezoid in outline and oval in cross-section (Pl. XXV, 5). In Aruba and Curaçao there are also true petaloid forms, tapering to a point. The finest example of this class, however, a large, highly polished celt with a fan-like cutting edge, has been found on the island of Bonaire (Pl. XXV, I). It is I6o $\mathrm{mm}$ in length, with a maximum width of $58 \mathrm{~mm}$ and a thickness of $34 \mathrm{~mm}$. Other stone celts are relatively flat, with parallel sides, rectangular cross-section, and rounded corners and a carefully ground cutting edge ( $\mathrm{Pl}$. XXV, 8 ).

It is interesting to note that all tools, with perhaps a few exceptions, are, as far as I am aware, of non-local igneous rock.

A second significant point is that, on the islands of Aruba and Curaçao, not only have completely finished stone celts been recorded, but also specimens in process of manufacture, some only chipped, others partially ground $(\mathrm{Pl}$. XXV, 3,4$)$. In view of these facts, it is suggested here that the stone celts were imported from the continent as 'blanks' and the grinding carried out later by the islanders. Similar stone artifacts are characteristic finds in the Falcón and Valencia areas but are unknown in Carache (CRUXent \& Rouse, I958, p. 7I. KiddeR, I944, p. I57).

Other stone artifacts can be summed up as follows: - A long narrow chisel with slightly converging side edges is known from Bonaire $(\mathrm{Pl}$. XXV, 2). It is $125 \mathrm{~mm}$ in length, its width at the 
butt-end is $23 \mathrm{~mm}$, width near the cutting edge $16 \mathrm{~mm}$, and greatest thickness I3 mm. One 'pygmy' chisel made of nephrite has been found in Aruba (Pl. XXV, II). It is only $29 \mathrm{~mm}$ long, Io $\mathrm{mm}$ wide, and $5 \mathrm{~mm}$ thick. Slightly bigger examples of this class are found in Curaçao and Bonaire (Pl. XXV, Io, II). Their number is small in proportion to that of the stone celts. All celts and chisels have bi-bevelled cutting edges. The stone objects include some knives. One specimen is large and flat, ground on both surfaces, with the bit on one of the long sides, the opposite side being blunt and slightly rounded (Pl. XXV, 6). It is I72 mm long, $6 \mathrm{I} \mathrm{mm}$ wide and II $\mathrm{mm}$ thick. The second large knife is roughly chipped, and unground. It is an unfinished specimen. Both knives were found in Aruba. At Santa Cruz, Aruba, a slingstone in the shape of an egg was found, with a longitudinal groove round its surface $(\mathrm{Pl} . \mathrm{XXV}, 7)$; in addition, numerous slightly-worked stone balls, hammerstones and some mortars and grinding stones were encountered. There are some objects of quartz and quarzite too, but it is not certain that these are of human manufacture. On the other hand, a miscellany of flakes made of 'knip'stone, with striking platform and bulb of percussion, which were found in an abri called Rooi Rincón, near Hato, in Curaçao, reveal what look like signs of human workmanship. Not much can be said about these nondescript flakes; they may, after all, be palaeoriths. Pieces of red and yellow ochre have been found at Santa Cruz, Aruba; it is possible that this haematite was used as a paint for body decoration and/or for rock paintings. Stone projectile points and true metates are completely absent.

\section{Bone Artifacts}

Very few bone objects from Aruba are available for study, and none are known from Curaçao and Bonaire.

In the first place we would call attention to a small flattened bone point, $42 \mathrm{~mm}$ long, $7 \mathrm{~mm}$ wide, and $5 \mathrm{~mm}$ thick (Pl. XXVI, 3). It was found in the lower part of the Santa Cruz site. Unfortunately, we have only one example of this class of tool, which may be a relic of an older, non-ceramic culture of the Cabagua complex, like that found on Margarita island (CRUXent \& RouSE, I948, p. 240). On one flattened surface, there is a groove along the axis of the object; it may have been used as a projectile point.

On the same site and in the same layer, a spatula of turtle bone 
was found; only the bit had been modified (Pl. XXVI, 2). It is I30 $\mathrm{mm}$ long, $53 \mathrm{~mm}$ wide, and Io $\mathrm{mm}$ thick. Similar tools are known from the Los Roques island group.

Little can be said about the third bone object, which is also made of turtle bone and perhaps represents a carving from an amulet, but is most difficult to define with any certainty (Pl. XXVI, I).

This is all we can say about bone artifacts. It is obvious that bone objects have played only a very minor part in the material culture of the three Dutch 'Islands Below The Wind'.

\section{CONCLUSIONS AND SUGGESTIONS}

We will now give a rather sketchy picture of the probable archaeology of the island of Aruba. It is based on archaeological data, but the vertical distribution suggested is partly theoretical.

In attempting to sum up the main evidence by looking at the overall picture of the archaeological finds of both utilarian and ornamental objects, one is struck by the apparent affinity with the Dabajuro style of Period IV. Du Ry pointed this out. However, many archaic tool types have been found, amongst them a few bone points and numerous shell gouges - objects which, according to RoUSE and CRUXENT, are reliable diagnostic dating material. Moreover, there is the intrusion into the finds of the earliest trade sherds. These facts taken in conjunction, suggest that at some remote age an archaic population of marginal, backward, non-ceramic coastal fishermen inhabited the island. It is not known when these people made their first appearance, since no non-ceramic shell middens containing shell gouges have yet been found. Nevertheless, I feel certain that such middens exist. It is not so very surprising that they have eluded searchers up till now, as shell heaps without potsherds are not spectacular and scanty since camps were moved frequently and are easily overlooked by the amateur archaeologist. To settle the problem, however, search for and excavation of pre-ceramic shell middens should be considered as an urgent necessity. With the help of carbon I4 dating the various chronological data could then be integrated.

It may well be that the earliest settlers on the island - who may perhaps have been of Ciboney origin - persisted for a long time. These people were probably responsible for the cave burials, and used slingstones, stone balls, and shell gouges. Then, 
at a not so remote time, farming Caquetíos immigrated into Aruba. They were good merchants and skilled navigators; they introduced agriculture and were responsible for the elaborate pottery and stone celts. They also carried out the secondary urnburials associated with peculiar anthropomorphic jars.

In the course of time, the two peoples and their respective cultures seem to have blended together peacefully. No doubt the newcomers to Aruba found the area suitable for cultivation rather small, but by way of compensation the sea offered reliable food supplies for the support of the population. A few crops were then raised, such as manioc and perhaps corn. Sea food, however, continued to be of great importance, and gardening, which was necessarily on a small scale, never became an important element of native life.

A lively trade was maintained, mainly by barter, between the islanders and the peoples on the mainland, and many foreign elements of culture found their way to the island. The onslaught of the Spaniards brought this civilization to an untimely end. In I5I5 most of the population were carried away into slavery.

As far as our present knowledge goes, Curaçao and Bonaire shared only the beginning of the archaeological pattern outlined above for Aruba. Many shell gouges have also been found in these two islands, and there is reason to believe that the original inhabitants, like those of Aruba, were peripherical, simple fisherfolk. It is obvious, however, that they suffered from a different type of invader. At first sight this may seem strange, as all three islands, Aruba, Curaçao and Bonaire, are geographically close together. It should be realized, however, that Aruba lies on a coastal shelf, which explains its intimate connection with the peninsula of Paraguaná, whereas Curaçao and Bonaire are real oceanic islands accessible only with great difficulty because of treacherous currents. It is, therefore, not really surprizing that, of these three islands in close proximity, Aruba shows an archaeological development along lines essentially different from that of Curaçao and Bonaire, especially in the later periods. These differences become particularly noticeable from a study of the ceramic finds and ornaments, and are also indicated, to a lesser degree, by the stone tools. It is too early to give an opinion as to the routes taken by the migrants to Curaçao and Bonaire. To solve these problems and generally to obtain a clearer picture of the re- 
lationship of those islands to the nearby continent, further investigations on the spot are needed.

After our brief survey and exposition of our ideas, we must not close this chapter without thanking Dr. P. WAGENAAR HummeLINCK for his important share in reviving archaeological interest in the area under discussion. His stimulating influence has been felt by us throughout our studies.

Our knowledge of the subject is still greatly limited through lack of systematic work. It is hoped that this survey will act as a stimulus to further research before it is too late. The archaeological sites and urn fields are still at the mercy of clandestine excavators and treasure hunters.

The time is not far off when complete destruction of the sites will make it impossible to carry out further scientific research against a background of systematic excavations, and that would be a great pity.

$$
\text { EXPLANATION OF PLATES }
$$

The specimens illustrated in the Plates are all in the National Museum of Ethnology (Rijksmuseum voor Volkenkunde) at Leiden, where they belong to the collections assembled by VAN KOOLWIJK and DE JOSSELIN DE JONG, which will be referred to as Kw and JJ. - Where the measurements are not given they may be calculated by comparison with the scale index (in $\mathrm{cm}$ ). The photographs were made by Mr. C. ZwANENBURG, Leiden.

\section{REFERENCES}

Bosch, G. B., 1836. Reizen in West-Indië, II. Utrecht.

Cruxent, J. M., 1955. Descripción de una colección arqueológica del municipio Dabajuro, Edo. Falcón (Venezuela). Memorias Soc. Cienc. Nat. la Salle 15, p. 89-113.

Cruxent, J. M. \& Rouse, Irving, 1958. An Archaeological Chronology of Venezuela, I. Social Science Monogr. 6, Pan-Amer. Union, Washington.

Du Ry, C. J., 1960. Notes on the pottery of Aruba, Curaçao and Bonaire. Nieuwe West-Indische Gids 40, p. 81-102. - Also in Uitgaven Naturwet. Werkgroep Ned. Antillen ro, Curaçao.

Feriz, Hans, 1959. Zwischen Peru und Mexico. Meded. Kon. Inst. Tropen Amsterdam 134 (Afd. Anthrop. 63). - Aruba und Bonaire: p. 98-136.

Ford, JAmes A., 1944. Excavations in the Vicinity of Cali, Colombia. Yale Univ. Public. Anthrop. 31. 
HooIJER, D. A., 1960. Mammalian remains from Indian sites on Aruba. Studies fauna of Curaşao and other Caribbean islands Io, Publ. Found. Sci. Res. Surinam and Neth. Antilles 21, p. 154-157.

Howard, George D., 1943. Excavation at Ronquin, Venezuela. Yale Univ. Publ. Anthrop. 27.

Howard, George D., 1947. Prehistoric Ceramic Styles of Lowland South America, their distribution and history. Yale Univ. Publ. Anthrop. 37.

JosSELIN DE JoNG, J. P. B. DE, I9I8. The praecolumbian and early postcolumbian aboriginal population of Aruba, Curaçao and Bonaire. Intern. Archiv. Enthnogr. 24, p. 51-II4.

Josselin DE JoNG, J. P. B. DE, 1920. De betekenis van het archaeologisch onderzoek op Aruba, Curaçao en Bonaire. West-Indische Gids I vol. 2, p. 317-334.

Josselin DE JONG, J. P. B. DE, 1923. The praecolumbian and early postcolumbian aboriginal population of Aruba, Curaçao and Bonaire. Intern. Archiv Enthnogr. 25, p. I-26. - Part I continued. (No more parts published.)

Josselin DE Jong, J. P. B. DE, 1923. Verslag van de Deensch-Nederlandsche Archaeologische Expeditie naar de Antillen. Bull. Maatsch. Natuurk. Onderzoek Nederl. Koloniën 79.

Josselin DE JONG, J. P. B. DE, 1924. A natural prototype of certain three-pointed stones. Proc. 2 I Intern. Congr. Americanists, p. 43-45.

Josselin de Jong, J. P. B. DE, 1947. Archaeological material from Saba and St. Eustatius, Lesser Antilles. Meded. Rijksmuseum Volkenkunde I.

KATE, H. TEN, 1916. Oudheden. Encyclopaedie van Nederlandsch WestIndië, 1914-1917, p. 541-546.

Kidder II, Alfred, 1944. Archaeology of Northwestern Venezuela. Papers Peabody Museum Amer. Archaeol. Ethnol. 26, no. r. Cambridge.

Koolwijk, A. J. van, r88I. De Indianen-Caraïben, oorspronkelijke bewoners van Curaçao. Tijdschr. Nederl. Aardrijksk. Genootschap 5, p. 57-68.

KoolwiJk, A. J. van, r882. De Indianen Caraỉben van het eiland Aruba (West-Indië). Tijdschr. Nederl. Aardr. Gen. 6, p. 222-229.

Leemans, r88o. Antiquités américaines récemment acquises pour le Musée Royal Néerlandais d'Antiquités à Leide. Compte Rendu 3 Congr. Americanistes, Bruxelles $1879, I$, p. 657-675.

Leemans, C., 1904. Altertümer von Curaçao, Bonaire und Aruba. Mitteilungen Niederl. Reichsmuseum Völkerkunde, Veröff. (2) 9, Beitr. Anthr. Ethn. Arch. Niederl. Westindiens, p. 7-17.

Nomland, Gladys Ayer, r933. Archaeological site of Hato Viejo, Venezuela. Amer. Anthropologist 35, p. 718-74r.

Nomland, Gladys Ayer, 1935. New Archaeological Sites from the State of Falcón, Venezuela. Ibero-Americana Ir.

Osgood, Cornelius, 1942. The Ciboney culture of Cayo Redondo, Cuba. Yale Univ. Publ. Anthrop. 25. 
ARCHAEOLOGY OF THE NETHERLANDS ANTILLES: II II9

Osgood, Cornelius, 1943. Excavations at Tocorón, Venezuela. Yale Univ. Publ. Anthrop. 29.

Osgood, Cornelius \& Howard, George D., 1943. An Archaeological Survey of Venezuela. Yale Univ. Publ. Anthrop. 27.

Pinart, A. L., I89o. Aperçu sur l'île d'Aruba, ses habitants, ses antiquités, ses pétroglyphes. - Blue-print of MS, published by WAGENAAR HumMELINCK, 1957, p. I22-I26.

Rouse, IRving, 1956. Settlement patterns in the Caribbean area. Prehistoric Settlement Patterns in the New World, ed. Gordon R. Willey, Viking Fund Publ. Anthrop. 23.

STEARNS, Richard E., 1945. Indian artifacts from the island of Aruba. Maryland, a Journal of Nat. Hist. 15, p. 34-39.

Steward, Julian H., ed., 1948. Handbook of South American Indians, IV. Bull. Bureau Amer. Ethnol. 143.

WagenaAR Hummelinck, P., 1953. Rotstekeningen van Curaçao, Aruba en Bonaire. (Linear rock designs of Curaçao, Aruba and Bonaire). WestIndische Gids 34, p. 173-209. - Issued separately in Uitgaven Natuurwet. Werkgroep Ned. Ant. 2, Curaçao.

WagenaAr Hummelinck, P., 1957. Rotstekeningen van Curaçao, Aruba en Bonaire, II. W. I. Gids 37, p. 93-126. - Uitgaven Natuurwet. Werkgroep Ned. Ant. 6.

WagenaAR Hummelinck, P., 1959. Indiaanse skeletvondsten op Aruba en Curaçao. (Indian skeletal discoveries in Aruba and Curaçao). W. I. Gids 39, p. 77-94. - Also in Uitgaven Natuurwet. Werkgroep Ned. Ant. 9.

\section{GLOSSARY}

The following terminology is described and presented to the general reader who may be unfamiliar with the nomenclature used in both articles. The greater part is borrowed from IRving Rouse, 1942, p. 167-169.

Anthropomorphic decoration: any decoration which seems to portray a human being.

Appliqué work: the process of laying strips of clay along the surface of a pot as a decoration.

Bowl: a pottery vessel which generally is hemispherical in shape and sometimes is elongated.

Bulb of percussion: a conical swelling on the flake surface arising from a point below the striking platform.

Griddle: a flat disc of clay, used for baking cassava- or mais pancakes.

Grinder or grinding stone: any stone, usually a water-worn pebble, bearing one or more facets which are smooth and seem to have been used for grinding or polishing.

Hammerstone: a stone having one or more battered facets which seem to have been used by hammering. 
Carbon I 4 dating: the decay of the radio-active isotope of Carbon $\mathrm{C}_{14}$ provides an accurate scale for determining in years. One ounce of $\mathrm{C} \mathrm{I}_{4}$ will be reduced by disintegration to one half ounce in 5568 years (pl. min. 30 years), and half of the remainder will decay during the next stated number of years a.s.o.

Celt: a long, narrow ax neither grooved nor notched.

Igneous rocks: rocks which have solidified, with cooling from magma or lava with or without actual crystalization.

Incision: the practice of tracing lines in the clay of pottery vessels, or in other material.

Lug: any lump-like projection which is affixed to the vessel in one spot, without being looped.

Manioc: cassava.

Metate: a three-legged flat grinding-stone to reduce the kernels of corn to flour.

Millstone or millingstone: a stone slab having a small, shallow depression in the upper surface, which seems to be the result of rubbing, grinding or hammering.

Negative design: the practice of outlining designs with the areas between incised or painted lines rather than with the lines themselves.

Nephrite: compact tremolite grading into green actinolite.

Non-ceramic shell middens: refuse shell heaps with shell tools but without potsherds.

Positive design: is the inverse of the negative design process and is used normally.

Punctuation: the process whereby the potter pressed a pointed or wedge-shaped tool into the clay and then removed it without drawing the tool along the surface of the pot.

Sheil' gouge: an implement made from the basilar part of the conch shell, triangular in shape, concavo-convex in cross section, and provided with a beveled cutting edge.

Shell tips or threepointers: a natural conoid knob of conch shell, roughly triangular in outline with concave base showing signs of artificial treatment.

Simple shell pendant: any pendant made simply by cutting or drilling a hole through the upper part of a shell.

Stone chisel: a stone implement having a long narrow body, nearly cylindrical in cross section, a blunt butt, and a sharp bit.

Striking platform: a projecting angle of a block of stone which is chosen, on which the flaking blow can conveniently be delivered in shaping a flint; the resulting flake shows a part of the striking platform at the top.

Zoomorphic decoration: any decoration which seems to portray an animal.

Over de in deze 'Studies on the archaeology of the Netherlands Antilles' I en II behandelde onderwerpen werden lezingen gehouden op de 28 ste Vergadering van de 'Natuurwetenschappelijke Studiekring voor Suriname en de Nederlandse Antillen', die op 26 juni 1959 in het Rijksmuseum voor Volkenkunde werd gehouden. De schrijvers zijn de 'Studiekring' dankbaar voor de financiēle steun welke het mogelijk maakte dat hun verhandelingen zo rijk werden geillustreerd.

November, 1959 . 